\title{
A field study in support of the monitoring of priority substances in German freshwater fish: derivation of fillet-to-whole fish conversion factors
}

\author{
Heinz Rüdel ${ }^{1 *} \mathbb{D}$, Georg Radermacher ${ }^{1}$, Annette Fliedner ${ }^{1}$, Nina Lohmann² and Anja Duffek ${ }^{3}$
}

\begin{abstract}
Background: Bioaccumulating contaminants in surface waters are preferably monitored in fish for assessing the related risks to and via the aquatic environment. Consequently, the European Water Framework Directive (WFD) requires a monitoring of certain priority substances such as mercury, polybrominated diphenyl ethers (PBDE), perfluorooctane sulfonic acid and its derivatives (PFOS), hexachlorobenzene (HCB), hexabromocyclododecanes (HBCDD) and polychlorinated dioxins/dioxin-like compounds (dioxins) in freshwater and coastal fish. Tissue levels have to comply with biota environmental quality standards (EQSs) given in Directive 2013/39/EU. EQSs are justified either by risks for human health (assessed on the basis of fillet) or secondary poisoning of wildlife (based on whole fish). To support the practical implementation of the WFD biota monitoring in Germany, comparative investigations of target fish species caught at six sites were performed.
\end{abstract}

Results: At each site, at least three fish species listed in a national guidance document were sampled (e.g., chub, roach, bream, perch). Beside biometric data, concentrations of seven priority substances were determined in pooled fillet and carcass samples and whole fish data were calculated. The EQSs for PBDE and mercury were exceeded in nearly all fillet and whole fish samples. PFOS was above the EQS at several sites especially in perch, while HCB exceeded the EQS only at one site (Elbe River). All fillet and whole fish samples complied with the EQSs for dioxins and HBCDD. Based on wet weight concentrations of a homogeneous set of 20 composite sample pairs of 3-5 yearold fish, the following fillet-to-whole fish conversion factors were derived: mercury 0.81, PBDE 5.4, HCB 3.6, PFOS 2.7, dioxins 5.3, and HBCDD 1.8.

Conclusions: Recommendations on selection of target fish species, age or tissue given by EU and national guidance documents are practical and feasible. However, further adjustments of the samplings such as the determination of site-specific length-age relationships are required from both ecological and risk assessment perspectives. The derived conversion factors allow the translation of fillet-to-whole fish concentrations (and vice versa), and thus the EQS compliance assessment for the appropriate tissue (fillet for human health, whole fish for wildlife risks) if only one tissue is investigated.

Keywords: Biota monitoring, Environmental quality standard, Fillet-to-whole fish conversion factor, Priority substances, Trophic level, Water Framework Directive

*Correspondence: Heinz.Ruedel@ime.fraunhofer.de

${ }^{1}$ Department Environmental Specimen Bank and Elemental Analysis, Fraunhofer Institute for Molecular Biology and Applied Ecology

(Fraunhofer IME), 57392 Schmallenberg, Germany

Full list of author information is available at the end of the article

\section{Background}

The European Water Framework Directive (WFD, Directive 2000/60/EC; [1]) requires a monitoring of the chemical status of all water bodies. While in the past the

\section{Springer Open}

(c) The Author(s) 2020. This article is licensed under a Creative Commons Attribution 4.0 International License, which permits use, sharing, adaptation, distribution and reproduction in any medium or format, as long as you give appropriate credit to the original author(s) and the source, provide a link to the Creative Commons licence, and indicate if changes were made. The images or other third party material in this article are included in the article's Creative Commons licence, unless indicated otherwise in a credit line to the material. If material is not included in the article's Creative Commons licence and your intended use is not permitted by statutory regulation or exceeds the permitted use, you will need to obtain permission directly from the copyright holder. To view a copy of this licence, visit http://creativeco mmons.org/licenses/by/4.0/. 
monitoring was based mainly on concentrations of substances in the water phase, now additional measurements of levels of certain bioaccumulating contaminants in organisms are required. Directive 2013/39/EU [2] introduced environmental quality standards (EQSs) for biota for eight priority substances (PS) or substance groups in addition to those already existing for three PS [3]. Nine of the biota-EQSs relate to fish, i.e., polybrominated diphenyl ethers (PBDE), hexachlorobenzene (HCB), chlorinated dioxins/furans and dioxin-like polychlorinated biphenyls (PCDD/F + dl-PCB), heptachlor and heptachlor epoxide, hexachlorobutadiene (HCBD), dicofol, hexabromocyclododecanes (HBCDD), perfluorooctane sulfonic acid and its derivatives (PFOS), and mercury $(\mathrm{Hg})$.

The objective of the WFD is a good status of water bodies and thus ultimately the protection of human health (risk of uptake of contaminated fish as food) and wildlife (risk of secondary poisoning of predators by feeding on contaminated prey). For these two protection goals quality standards were derived with the lower value being used as EQS [4]. The EQSs for PBDE, HCB, $\mathrm{PCDD} / \mathrm{F}+\mathrm{dl}-\mathrm{PCB}$, heptachlor and heptachlor epoxide and PFOS are human health based while for HCBD, dicofol, HBCDD, and mercury the EQSs are based on the secondary poisoning of predators [5]. When assessing EQS compliance, PS concentrations are usually evaluated by analyzing fillet for human health-based EQSs or whole fish for wildlife risk-based EQSs [5].

The present study was initiated to support the development of a suitable fish monitoring concept that meets the requirements of the EQS directive 2013/39/EU [2] and other requirements in the WFD context. In Germany, the EQS directive was implemented with the Surface Water Ordinance (German abbreviation OGewV; [6]). The requirements of the EQS directive and the OGewV on biota monitoring are substantiated in two documents, the EU Guidance Document No. 32 on Biota Monitoring [5], and the Working Paper IV.3 on the "Framework Concept Monitoring" (German abbreviation RAKON) of the German Working Group of the Federal States on Water Issues [7] which includes, for example, recommendations on fish species, fish age, tissue selection and fish numbers.

The aim of the current study was to assess the practical feasibility of the specifications given in the guidance documents. To this end, from six German water bodies fish of three different species were sampled in two different age classes (if available) to allow comparing their suitability for monitoring purposes. Fish biometric data were recorded and fillets dissected. For both fillet and carcass (the remaining fish without fillet) concentrations of selected PS were determined and evaluated.
Existing monitoring data from Germany (e.g., [8-11]) indicate that concentrations of dicofol and HCBD in fish from German waters are consistently below the EQSrelevant limit of quantification (LOQ; i.e., LOQ $<30 \%$ of EQS [12]). Thus, these two substances were not considered for analysis here since it was not expected that sufficient data above the LOQ could be obtained that would allow a further evaluation and discussion of the data. This decision also reduced the amount of tissue required for PS analysis.

The focus of the present work was on the following questions: are the recommendations regarding the fish species applicable? Should fillet or whole fish be analyzed? How much fish tissue is required for the analysis? Do older fish have higher PS burden than younger ones? Which trophic level should the fish represent? Can factors be derived to convert fillet concentrations of contaminants into whole fish concentrations (or vice versa)? Based on results derived from this study and additional literature data, the practical implications of the mentioned aspects for an appropriate surface water monitoring of contaminants in fish to determine EQS compliance are discussed.

\section{Methods \\ Sampling sites}

Fish samples were taken from six freshwater sites located in the rivers Weser (locations Drakenburg, geo-coordinates latitude N 52.694801/longitude E 9.200792, and Schweringen, N 52.745265/E 9.199784; distance about $10 \mathrm{~km}$, the site Schweringen is downstream a barrage), Elbe (Schönebeck, N 52.023574/E 11.739696), Moselle (Mehring, N 49.792293/E 6.82017 and Kenn, N 49.821134/E 6.712378, about $15 \mathrm{~km}$ upstream), and Havel (the lake-like section "Grosser Wannsee", N 52.432034/E 13.172567), and in Lake Starnberg (N 47.9001/E 11.3168), and the coastal water lagoon "Kleines Haff" of the Baltic Sea (N 53.813548/E 14.105501). Each site was sampled once in late summer, either in 2016 (Weser, Havel, Elbe) or in 2017 (Moselle, Lake Starnberg, Kleines Haff).

\section{Fish sampling}

At each site three different fish species were sampled, i.e., chub (Squalius cephalus; according to www. fishbase.org [13] trophic level $\mathrm{TL}=2.7 \pm 0.1$ ), roach (Rutilus rutilus; $\mathrm{TL}=3.0 \pm 0.0$ [13]), bream (Abramis brama; $\mathrm{TL}=3.1 \pm 0.1$ [13]), perch (Perca fluviatilis; $\mathrm{TL}=4.4 \pm 0.0$ [13]), and whitefish (Coregonus renke; $\mathrm{TL}=3.4 \pm 0.3$ [13], only recommended for lakes). These species are recommended in the RAKON Working Paper [7] for monitoring in rivers, lakes and coastal waters of the North and Baltic Seas. 
Fish sampling was performed either by authorized fishermen or by federal state authorities by means of electrofishing (Elbe, Weser) or appropriate nets for fish of the intended size (other sites). Killed fish were immediately stored in ice. The aim was to catch 20 fish of each species in two size classes. If possible, one of the size classes should comply with the recommendations given in the RAKON Working Paper [7] for 3- to 5-year-old roach or 3- to 4-year-old individuals of the other species, while the other size class should cover larger fish. The respective recommended size classes (total fish length) are: chub 23-30 cm, roach $15-22 \mathrm{~cm}$, bream $20-27 \mathrm{~cm}$, perch $15-20 \mathrm{~cm}$, and whitefish $28-35 \mathrm{~cm}$ [7]. In total about 60 fish were selected per site.

\section{Processing of fish}

Fish from Weser and Havel were dissected on-site within $24 \mathrm{~h}$ after sampling. At all other sites, fish were stored in ice directly after sampling, transported to the laboratory and processed within $48 \mathrm{~h}$ (up to $72 \mathrm{~h}$ for a few fish from the Elbe).

Biometric data (fish size, weight and sex, if assignable) were documented. Of each fish, one fillet without skin was removed. Only in case of very small fish (weight of one fillet $<20 \mathrm{~g}$ ) both fillets were sampled. The weights of the fillet and the carcass were documented. For the preparation of the carcass samples, the remaining fish (including the viscera) and the skin of the fillet were combined. From about $40 \%$ of the fish liver and brain were sampled for other studies. It is assumed that the effect of the organs not included in the carcass samples on the carcass concentration data is negligible in view of the measurement uncertainty (see assessment in Additional file 1: "Exemplary calculation showing the possible influence of removing livers and brains from some carcass samples on the PS concentrations in the carcass samples" section). Age was determined by Institut für angewandte Ökologie (Kirtorf-Wahlen, Germany) by examination of several scales per fish as described in [14]. Data are given as years $(y)$.

Fish tissues were frozen in liquid nitrogen immediately after dissection and stored in containers in the gas phase above liquid nitrogen at temperatures below $-150{ }^{\circ} \mathrm{C}$ [15].

Sample treatments followed procedures of the German Environmental Specimen Bank (ESB) program $[8,16]$. Frozen fillet and carcass samples were manually crushed and afterwards cryo-milled as described elsewhere [16, 17].

\section{Preparation of composite samples}

In accordance with RAKON Working Paper [7], fish were selected and assigned to site-specific composite samples on the basis of the determined fish age. For fillets and carcasses, separate composite samples were prepared. Fish not falling into the target age class were combined to further homogeneous composite samples based on length, weight, sex or on random assignment. If possible, two composite samples per species and site were prepared.

Composite samples were prepared by combining proportional tissue masses of each of about 10 fish. Thus, larger individuals contribute more mass to the respective composite sample than smaller ones. This approach simulates the actual risk for predators in waters and the risk for human health as well, because predators take up whole fish of different size and fillets of these fish contribute proportionally to the human diet.

\section{Trophic level determinations}

Nitrogen stable isotope determinations $\left({ }^{15} \mathrm{~N} /{ }^{14} \mathrm{~N}\right.$ and ${ }^{13} \mathrm{C} /{ }^{12} \mathrm{C}$ ratios) of carcass composite samples after lipid extraction were performed by agroisolab $\mathrm{GmbH}$ (Jülich, Germany). Data were expressed as per mill $\delta^{15} \mathrm{~N}$ and $\delta^{13} \mathrm{C}$ and evaluated for fish trophic level (TL) as described elsewhere [16, 18]. Mussels (Dreissena ssp; additionally Corbicula ssp. at Elbe River) sampled from each site parallel to the fish were used as baseline organisms (filter feeders; assigned TL $=2.0$ [18]). A $\delta^{15} \mathrm{~N}$ increment of 3.4 per mill for a TL difference of 1 was applied [18].

\section{Analysis of fish samples}

PS analysis followed WFD requirements [2] and technical specifications [12]. Details have been described previously $[8,16,19,20]$. Thus, only short summaries are presented here.

The total mercury analyses of freeze-dried individual fish and composite samples of fillets and carcasses were carried out by Fraunhofer IME in accordance with a guideline issued by the German Environmental Specimen Bank [21] using a mercury solids analyzer protocol (Direct Mercury Analyzer DMA-80, MLS GmbH, Leutkirch, Germany) as described elsewhere [22].

Fillet and carcass composite samples were analyzed for organic PS by Eurofins GfA Lab Service GmbH (Hamburg, Germany) following previously described isotope dilution methods with suitable isotope-labeled standards of the target compounds. Detailed descriptions of all protocols applied here are available elsewhere $[8,20]$. In short, $\mathrm{PCDD} / \mathrm{F}+\mathrm{dl}-\mathrm{PCB}$ were extracted with appropriate organic solvents (e.g., toluene or hexane/dichloromethane) from fillet and whole fish composite samples, the extracts were purified by column chromatography (involving sulfuric acid-treated silica as well as aluminum oxide) and analyzed by high-resolution gas chromatography/mass spectrometry coupling (HRGC/HRMS with sector field instrument). The data are reported in 
accordance with WFD requirements as sums of toxicity equivalents excluding concentrations below the LOQ [12], taking into account the toxic equivalency factors (TEQ) of the World Health Organization of 2005 (as $\mu \mathrm{g} \mathrm{kg}^{-1} \mathrm{WHO}_{2005}$-TEQ; [23]). PBDE were extracted from freeze-dried samples and the extracts were purified and quantified by gas chromatography/mass spectrometry (GC-MS). Results are reported EQS-conform as sum of six congeners (BDE 28, BDE 47, BDE 99, BDE 100, BDE 153 and BDE 154) without consideration of congener concentrations below LOQ [12]. HBCDD was extracted from biota samples after freeze-drying and the $\alpha-, \beta$ - and $\gamma$-diastereomers were quantified by liquid chromatography/tandem mass spectrometry (LC-MS/MS) after purification of the extracts. Perfluorinated alkyl substances (PFAS) including PFOS were extracted from freeze-dried samples, the extracts were purified by dispersive solid phase extraction with activated carbon and quantified by LC-MS/MS. HCB was extracted after mixing the biota sample with sodium sulfate. The extracts were purified by column chromatography and analyzed by GC-HRMS.

The water content was determined gravimetrically by weighing of sample aliquots before and after freeze-drying. The fat content of all composite samples was determined according to Smedes [24].

\section{Quality assurance/quality control}

The laboratories hold DIN EN ISO/IEC 17025 accreditations for the applied analytical methods. All respective quality assurance/quality control (QA/QC) requirements were met. Various measures were taken to ensure the quality of the analytical results. In the course of the investigations, blank samples were analyzed parallel to the fish samples, which, however, did not reveal any indications of possible contamination of the samples by the chemicals or laboratory equipment used. To prove the reproducibility, quality assurance samples were analyzed parallel to each set of samples yielding similar results under consideration of the measurement uncertainty. The accuracy of the analytical results was assured by regular analysis of certified reference materials (CRMs) and by regular successful participation in interlaboratory proficiency tests, e.g., organized by QUASIMEME (www. quasimeme.org).
Recovery rates of isotope-labeled internal standards used for calculation of organic PS concentrations in fillet/ carcass composite samples following the isotope dilution method were determined for each sample applying the following criteria for acceptance of data: PCDD/F $+\mathrm{dl}-$ PCB $60-120 \%$, PBDE, HCB and HBCDD: $50-120 \%$; PFOS $40-150 \%$.

Limits of quantification (LOQs) were determined following either the "calibration line approach" of the German standard DIN 32645:2008 [25], using the signal/ noise ratio, or on basis of the standard deviation of replicate measurements at the expected LOQ level.

For mercury, the LOQ was $0.4 \mu \mathrm{g} \mathrm{kg}^{-1}$ dry weight corresponding to about $2 \mu \mathrm{g} \mathrm{kg} \mathrm{kg}^{-1}$ wet weight (ww) depending on the tissue water content. All recoveries for mercury in CRMs were in the range of $80-120 \%$ of the certified values. The LOQs for congeners of PCDD/F were $0.000013-0.00039 \mu \mathrm{g} \mathrm{kg}^{-1} \mathrm{ww}$, for congeners of dl-PCB $0.00018-0.0093 \mu \mathrm{g} \mathrm{kg} \mathrm{kg}^{-1} \mathrm{ww}$, for congeners of PBDE $0.0048-0.0060 \mu \mathrm{g} \mathrm{kg}{ }^{-1} \mathrm{ww}$, for $\alpha-, \beta$ - and $\gamma$-HBCDD $0.0060 \mu \mathrm{g} \mathrm{kg}^{-1} \mathrm{ww}$, for PFOS $0.050 \mu \mathrm{g} \mathrm{kg}{ }^{-1} \mathrm{ww}$, for HCB $0.035 \mu \mathrm{g} \mathrm{kg}^{-1} \mathrm{ww}$, and for heptachlor/heptachlor epoxide $0.050 \mu \mathrm{g} \mathrm{kg}^{-1} \mathrm{ww}$. The requirement of Directive 2009/90/EC [12] that the LOQ should be equal or below a value of $30 \%$ of the relevant EQS was fulfilled for all PS except for heptachlor/ heptachlor epoxide (LOQ > EQS) and PBDE (LOQ only at $60-70 \%$ of the EQS).

The measurement uncertainty of each parameter was determined taking into account precision data from validations and evaluations of laboratory control charts. The uncertainty of the total mercury measurement was $3-5 \%$ in the medium measuring range of the analysis method and $5-10 \%$ in the range of the LOQ. In the range of the EQSs the uncertainty of measurement for the organic PS was about 15\%. For all parameters WFD requirements were fulfilled (extended uncertainty calculated with $k=2$ below $50 \%$ ) [12].

\section{Calculation of whole fish concentrations}

In this contribution, we are using the term "concentration" for the measured PS mass fractions in fish tissues. Whole fish concentrations for all analytical parameters were calculated from the tissue weights determined during dissection (Additional file 1: Table S1) and measured concentrations in fillet and carcass composite samples [16, 26] (Eq. 1):

$$
\operatorname{Conc}(\text { whole fish })=\frac{[(\text { Weight }(\text { whole fish })-\text { Weight }(\text { fillet })) \times \text { Conc }(\text { carcass })]+[\text { Weight }(\text { fillet }) \times \text { Conc }(\text { fillet })]}{\text { Weight }(\text { whole fish })} \text {. }
$$


Calculations were based on the PS data of fillet and carcass composite samples. In the case of mercury, additionally data for individual fish were calculated accordingly.

It is assumed that the calculated values for whole fish correspond to those, which would have been obtained by analyses of the original fish when considering the measurement uncertainties of the analytical methods (see "Quality assurance/quality control" section).

\section{Determination of fillet-to-whole fish conversion factors and equations}

As recommended by the EU Guidance Document on Biota Monitoring [5], the approach by Bevelhimer et al. [26] was used here for the conversion of pollutant levels in fillets to whole fish and vice versa. The first step involved testing the correlations between the pollutant concentrations in fillet and in whole fish composite samples. Depending on the quality of the correlation, either a constant factor or a conversion equation (regression function) is more appropriate for the calculation [26].

Outliers were identified by using the Grubbs' test successively. Before removing, it was checked whether a reason could explain the value being an outlier. Since not all data sets were normally distributed, the concentration values were logarithmized for the correlation analysis [26]. The evaluation was done for the whole data set ( $n=36$ fillet/whole fish composite sample pairs) and then for the data set with the fish aged 3-4 years/3-5 years according to the RAKON working paper [7] ( $n=20$ fillet/ whole fish composite sample pairs).

In order to test whether differences between logarithmized PS concentrations of fillet/whole fish composite sample pairs are significant a paired $t$ test was performed. If this test was positive, the correlation between (logarithmic) fillet/whole fish concentrations was evaluated for its significance (criterion: $p<0.05$ ). For the slope of the regression equation, it was tested whether it was different from zero. If yes, either a conversion factor was derived (slope not significantly different from 1) or the regression equation was used for the conversion (slope significantly different from 1) [26].

\section{Results and discussion}

\section{Characterization of fish catches}

Data on fish catches are listed in Additional file 1: Table S1. Biometric data (length, weight, age, sex) are given per species as aggregated values for all sites and for each location separately. In some cases, age determination based on fish scales was not possible; especially for older perch the determination was difficult. In such cases, the age was estimated from comparable large fish of the same catch, for which an age determination was possible (same species, same site). Likewise, sex could not be determined for all fish (especially not for younger fish). Of the 365 evaluated fish, 28\% were male, $51 \%$ female and $21 \%$ of unclear sex.

Additionally, the condition factor (CF) was calculated as follows: $\mathrm{CF}=100 *($ weight $[\mathrm{g}]) /(\text { length }[\mathrm{cm}])^{3}$. The CF serves as relative measure for the general fish condition (fish with higher CF reveal a better condition). Data are presented in Additional file 1: Table S1. Because the morphologies differ, only CFs of fish of the same species can be compared with each other.

At the sites in Weser and Moselle Rivers, sufficient numbers of chub were available. The fish were comparable in terms of length, weight and age with somewhat higher values for the Weser fish (Additional file 1: Table S1). In contrast, the number of chub from the Elbe was low and the sizes of the individuals were heterogeneous ( $n=4$; three of them large/old fish). Overall, the chubs from all sampling sites were mostly older than the recommended age of 3-4 years. The CF for chub from the Weser $(1.3 \pm 0.1)$ were significantly higher than for chub from the Moselle $(1.1 \pm 0.1)$, while Elbe chub had a medium CF $(1.2 \pm 0.03)$.

Roach were found in sufficient numbers at all six sites. The age distribution, however, was different. The on average youngest (as well as the smallest/lightest) roach were caught at the Weser site. Several individuals had the intended age of 3-5 years. The oldest (longest/heaviest) roach were sampled at the Elbe and Havel sites. At all locations except for Lake Starnberg, more female than male roach were caught. At the Weser site, however, sex determinations were not possible. In the Havel, almost only female specimens were caught (19 out of 21, two of unclear sex). The average CF of the roach from the Havel and the Baltic Sea lagoon was $1.3 \pm 0.1$ and thus slightly higher compared to the other sites (about 1.2; Additional file 1: Table S1).

Bream were found in sufficient numbers at only three sampling sites. Almost all specimens were older than the target age of 3-4 years recommended by the RAKON Working Paper [7]. Lengths and weights of the bream were comparable at all sampling locations. The oldest specimens came from the Havel site. It is noticeable that the relatively young bream from the Baltic Sea lagoon already had similar lengths and weights as the individuals from the Havel (i.e., $37 \pm 3 \mathrm{~cm}$ vs. $38 \pm 9 \mathrm{~cm}$, and $616 \pm 172 \mathrm{~g}$ vs. $699 \pm 466 \mathrm{~g})$ and also the highest CF $(1.2 \pm 0.1$ vs. $1.1 \pm 0.1$; Additional file 1 : Table S1).

Whitefish (C. renke) were only caught in Lake Starnberg. All individuals had the intended age of 3-4 years, 
but were smaller than the size specified for this age group in the RAKON Working Paper [7].

Perch were sufficiently abundant at all sampling sites except at the Elbe where only a few individuals were found. In Weser and Elbe, smaller/lighter/younger specimens were caught compared to the other sites. The largest and heaviest perch were from the Moselle site, followed by those from the Baltic Sea lagoon and the Havel. The CF ranged between 1.2 (Havel River) and 1.4 (Baltic Sea lagoon).

\section{Fish length-age relationships}

For orientation purposes, a correlation between fish length and age classes is presented in the RAKON Working Paper [7] for those fish species recommended for biota monitoring in German waters. Since the fish length is easy to determine during sampling, it shall be used to obtain fish of the intended age group on site. In the present study, these specifications were compared to the length-age relationships determined here.

Length-age relationships determined for roach and perch are shown in Additional file 1: Figure S1. For both species, significant relationships between fish length and age were detected. Diagrams of length vs. age for the intended age windows for roach (3-5 years) and perch (3-4 years) are shown in Additional file 1: Figure S2. For the other species, the data base for length-age relationships was too small (only roach and perch were found at all sites). Especially for perch it is obvious that the size window for 3-4 years individuals as given in the RAKON Working Paper [7] is only a rough guidance for sampling the intended age group. At Lake Starnberg, for example, perch of this age were often smaller than $15 \mathrm{~cm}$ (lower size range in [7]). By contrast, 4-year-aged perch from the Havel River and the Baltic Sea lagoon were larger than $20 \mathrm{~cm}$ (upper size given in [7]). For roach the lower size range $(15 \mathrm{~cm}$ as given in [7]) fits quite well (only one smaller fish at Lake Starnberg). However, at most of the other sites, 4- to 5-year-aged roach had sizes clearly above the upper size range of $22 \mathrm{~cm}$ (up to $>27 \mathrm{~cm}$ at Elbe and Moselle Rivers).

\section{Characterization of the composite samples}

Fish composite samples were characterized by fish mean length, age and trophic level (as determined from $\delta^{15} \mathrm{~N}$ ). Data are compiled in Table 1. Main criterion for the forming of the composite samples was the actual determined age of the fish. In some cases, a larger number of fish had the same age but could be distinguished additionally by length, sex or slightly different sampling locations so that these criteria were used for the allocation of fish to composite samples. In two cases, fish were randomly distributed to two separate composite samples with individuals of the same age (Weser perch, Baltic Sea bream; Table 1).

The lowest number of fish in a composite sample was 6 , the highest 13 . Of the total 36 composite samples, 20 consisted of fish belonging to the age classes recommended for the respective fish species in the RAKON Working Paper [7]. Only for seven of these composite samples did the fish sizes also correspond to the speciesspecific length ranges given in the RAKON Working Paper for fish of the intended age classes (Table 1).

The calculated trophic positions of the fish partly deviated from those expected from reference data ([13]; see "Fish sampling" section). Roach and bream had mainly TLs of about 3 as expected. For chub, the calculated TLs were higher than the reference TL of 2.7 [13]. In Weser and Moselle, chub had TLs of 2.9-3.3, which were only slightly lower than the TLs of roach at these sites (Table 1). Trophic positions of perch, on the other hand, were consistently lower than the expected TL of 4.4 (i.e., only TL 3.3-4; Table 1). At most sites, clear differences between trophic positions could only be determined between chub/roach/bream and perch. It remains unclear whether the trophic position of perch in these waters was actually lower than expected or whether the applied $\delta^{15} \mathrm{~N}$ increment of $3.4 \%$ per TL is inappropriate (although it is broadly used, also for river food web studies, e.g., [27]). However, for the TL difference of about 1 between the mussels (baseline, assigned $\mathrm{TL}=2$ ) and roach and bream (TL about 3) the chosen $\delta^{15} \mathrm{~N}$ increment fitted. Variations of up to $\pm 1 \mathrm{TL}$ for fish of the same species from different rivers were also reported in previous studies [27]. Moreover, for river fish, Rybczynski et al. [28] observed a good agreement between TL derived from gut analysis and TL based on stable isotope data as applied here. The TL data given in the reference database [13] used here are also based on analyses of food items in fish guts.

The fat content of the residual fish fraction was significantly higher than that of fillets. Since the mass of the residual fish was greater than the fillet mass, the calculated fat contents for the whole fish were also higher than the fillet fat contents (Additional file 1: Table S2). The fat content ranged between 0.6 and $2.6 \%$ (mean \pm SD: $1.5 \pm 0.5 \%$; median $1.4 \% ; n=36$ ) in fillets and between 1.6 and $8.4 \%(5.2 \pm 1.6 \%$; median $5.3 \% ; n=36)$ in whole fish. Fish from the Baltic Sea lagoon and the Weser River had particularly high fat contents. The highest average fat contents in whole fish were found in chub and roach (mean value of all sites: $5.5 \pm 1.1 \%, n=5$, and $6.1 \pm 1.1 \%$, $n=12$, respectively), the lowest in perch (mean values of all sites: $4.2 \pm 1.6 \%, n=11)$. In fillet, fat contents were also lowest in perch (mean value of all sites: $0.9 \pm 0.2 \%, n=11$ ), while highest contents were detected 
Table 1 Characterization of the fish composite samples by number of fish, age and length ranges, and trophic level (TL; calculated from $\delta^{15} \mathrm{~N}$ )

\begin{tabular}{|c|c|c|c|c|c|}
\hline Species & Sample code & Number of fish (remark) & Age (range) [years] & Length range $[\mathrm{cm}]$ & $\begin{array}{l}\text { TL for whole fish } \\
\left(\delta^{15} \mathrm{~N} \text { based }\right)^{\mathrm{c}}\end{array}$ \\
\hline \multicolumn{6}{|l|}{ Weser } \\
\hline Chub $1^{\mathrm{b}}$ & W-C1 & 6 & $4 \pm 1(3-4)$ & $24.5-31.5$ & 3.2 \\
\hline Chub 2 & W-C2 & $7(\leq 30.0 \mathrm{~cm})$ & $5 \pm 0(5-5)$ & $27.5-30.0$ & 3.2 \\
\hline Chub 3 & W-C3 & $6(>30.0 \mathrm{~cm})$ & $5 \pm 0(5-5)$ & $31.5-33.5$ & 3.3 \\
\hline Roach 1 & W-R1 & 6 (Schweringen) & $2 \pm 0(2-2)$ & $14.5-16.0$ & 3.3 \\
\hline Roach $2^{\mathrm{a}}$ & W-R2 & 9 (Schweringen) & $3 \pm 0(3-4)$ & $15.5-17.0$ & 3.2 \\
\hline Perch $1^{b}$ & W-P1 & 9 (random) & $3 \pm 1(3-4)$ & $16.0-21.0$ & 3.5 \\
\hline Perch $2^{b}$ & W-P2 & 9 (random) & $3 \pm 0(3-4)$ & $16.5-21.0$ & 3.4 \\
\hline \multicolumn{6}{|l|}{ Elbe } \\
\hline Roach $1^{\mathrm{b}}$ & E-R1 & 12 & $4 \pm 1(3-5)$ & $14.0-24.0$ & 3.1 \\
\hline Roach 2 & $\mathrm{E}-\mathrm{R} 2$ & 6 & $6 \pm 0(6-6)$ & $24.0-30.5$ & 3.1 \\
\hline Bream 1 & $\mathrm{E}-\mathrm{B} 1$ & 9 & $5 \pm 1(5-6)$ & $26.5-30.0$ & 3.2 \\
\hline Bream 2 & E-B2 & 9 & $10 \pm 1(8-11)$ & $47.0-51.0$ & 2.9 \\
\hline Perch $1^{\mathrm{a}}$ & E-P1 & 11 & $4 \pm 1(3-4)$ & $15.0-18.5$ & 3.5 \\
\hline \multicolumn{6}{|l|}{ Moselle } \\
\hline Chub $1^{\mathrm{a}}$ & $\mathrm{M}-\mathrm{C} 1$ & 6 (Kenn) & $4 \pm 1(3-4)$ & $23.0-28.5$ & 2.9 \\
\hline Chub $2^{\mathrm{a}}$ & $\mathrm{M}-\mathrm{C} 2$ & 10 & $3 \pm 0(3-4)$ & $23.5-27.5$ & 3.0 \\
\hline Roach $1^{\text {a }}$ & $M-R 1$ & 8 & $3 \pm 0(3-3)$ & $18.5-19.0$ & 3.0 \\
\hline Roach $2^{b}$ & $M-R 2$ & 8 & $5 \pm 0(4-5)$ & $26.0-29.0$ & 3.1 \\
\hline Perch $1^{\mathrm{a}}$ & M-P1 & 7 & $4 \pm 0(3-4)$ & $16.5-18.0$ & 3.9 \\
\hline Perch 2 & $M-P 2$ & 9 & $8 \pm 1(6-9)^{c}$ & $25.5-30.5$ & 3.8 \\
\hline \multicolumn{6}{|l|}{ Havel } \\
\hline Roach $1^{b}$ & $\mathrm{H}-\mathrm{R} 1$ & 7 & $5 \pm 0(4-5)$ & $21.0-27.0$ & 3.3 \\
\hline Roach 2 & $\mathrm{H}-\mathrm{R} 2$ & 13 & $7 \pm 1(6-8)^{c}$ & $25.5-32.0$ & 3.2 \\
\hline Bream 1 & $\mathrm{H}-\mathrm{B} 1$ & 10 & $7 \pm 1(6-8)$ & $26.0-33.0$ & 2.9 \\
\hline Bream 1 & $\mathrm{H}-\mathrm{B} 2$ & 10 & $13 \pm 2(11-15)$ & $42.0-50.0$ & 3.1 \\
\hline Perch $1^{b}$ & $\mathrm{H}-\mathrm{P} 1$ & 10 & $4 \pm 0(4-4)$ & $17.0-23.0$ & 3.8 \\
\hline Perch 2 & $\mathrm{H}-\mathrm{P} 2$ & 6 & $7 \pm 1(6-8)$ & $25.0-30.0$ & 4.0 \\
\hline \multicolumn{6}{|l|}{ Lake Starnberg } \\
\hline Roach $1^{\mathrm{b}}$ & S-R1 & 7 male & $4 \pm 1(3-5)$ & $15.0-23.0$ & 3.5 \\
\hline Roach $2^{\text {b }}$ & S-R2 & 7 female & $4 \pm 1(3-5)$ & $14.0-23.0$ & 3.1 \\
\hline White fish $1^{\mathrm{b}}$ & S-W1 & 13 & $4 \pm 0(3-4)$ & $25.5-30.0$ & 3.4 \\
\hline White fish 2 & S-W2 & 7 & $5 \pm 0(5-5)$ & $28.5-32.0$ & 3.6 \\
\hline Perch $1^{\mathrm{b}}$ & S-P1 & 11 & $4 \pm 1(3-4)$ & $12.5-16.0$ & 3.6 \\
\hline Perch 2 & S-P2 & 9 & ca. $8(7-9)^{c}$ & $21.5-26.0$ & 3.6 \\
\hline \multicolumn{6}{|c|}{ Baltic Sea lagoon } \\
\hline Roach $1^{\mathrm{b}}$ & $\mathrm{K}-\mathrm{R} 1$ & 12 female & $5 \pm 1(4-5)$ & $21.0-26.0$ & 3.0 \\
\hline Roach $2^{\mathrm{a}}$ & $\mathrm{K}-\mathrm{R} 2$ & 6 male & $4 \pm 0(4-5)$ & $20.5-22.0$ & 3.1 \\
\hline Bream 1 & K-B1 & 8 (random) & $6 \pm 1(5-7)^{c}$ & $34.5-39.5$ & 2.8 \\
\hline Bream 2 & $\mathrm{~K}-\mathrm{B} 2$ & 8 (random) & $6 \pm 1(5-7)$ & $35.5-40.5$ & 2.9 \\
\hline Perch $1^{b}$ & K-P1 & 9 & $4 \pm 0(4-4)$ & $19.5-21.0$ & 3.3 \\
\hline Perch 2 & $\mathrm{~K}-\mathrm{P} 2$ & 11 & $6 \pm 1(5-6)^{c}$ & $22.5-24.5$ & 3.4 \\
\hline
\end{tabular}

a Fulfills age and length criteria according to the RAKON Working Paper [7]

b Fulfills age criterion according to [7]

c Age determination not possible for all fish

d Remarks: random—fish of the same age, randomly assigned to two different composite samples; Schweringen—fish were sampled about $10 \mathrm{~km}$ downstream of the main location; Kenn-fish were sampled about $15 \mathrm{~km}$ upstream of the main location 
in whitefish, roach and bream (mean values: $1.9 \pm 0.1 \%$, $n=2$, for whitefish, $1.9 \pm 0.5 \%, n=12$, for roach, and $1.7 \pm 0.4 \%, n=6$, for bream of all sites).

Generally, whole fish had a higher dry mass content than fillet (about 20-29\% vs. about 14-20\%; Additional file 1: Table S2). In the fillet composite samples, the highest average dry mass content was found for whitefish $(19.4 \%)$ and the lowest for perch and bream $(17.2 \%$ and $17.3 \%$, respectively). For whole fish, the composite samples of roach had the highest dry mass content $(26.1 \%$ on average) and those of whitefish the lowest (22.1\%).

\section{Mercury concentrations in individual fish samples}

The total amount of available sample material was limited (especially for fillet). Therefore, only one PS (mercury) could be measured also in individual fish (fillets and carcasses) because the measurement requires only a small amount of sample material. The data were aggregated per species for fish aged $<10$ years (the number of older fish was only low and may bias the evaluation due to higher mercury concentrations) and fish in the age-window recommended for monitoring (Table 2). The mercury concentrations in bream and roach were below the average of all fish samples and those in perch above the average. Even for the fish aged 3-4/5 years, the mercury levels did not correlate to the trophic level (e.g., chub had higher mercury levels than bream and roach although the TL of chub is lower).

For fish aged 3-4 years (3-5 years for roach), the relationship between fish length and mercury concentration was evaluated. Additional file 1: Figure S3 shows the diagram for mercury concentrations in whole fish vs. fish length for all sites $(n=184)$. Mercury levels decreased slightly (not significant) with increasing fish length. If only fish from one site are considered, correlations between mercury levels and fish length are inconsistent: at some sites, $\mathrm{Hg}$ concentrations in whole fish decrease with fish length, while at others $\mathrm{Hg}$ levels increased with length (Additional file 1: Figure S4). Only for the fish from Weser River and Lake Starnberg, significant positive correlations were found between fish length and $\mathrm{Hg}$ concentration in whole fish $(n=33, p=0.019$ and $n=40, p=0.001$, respectively; Additional file 1: Figure S4). Including more than one site in the analysis [possible for chub ( 2 sites), roach (6 sites) and perch (6 sites)] also gave contradictory results. While for chub a significant increase of whole fish $\mathrm{Hg}$ concentrations with increasing length was observed ( $n=23$, slope $2.7 \mu \mathrm{g} \mathrm{kg}^{-1}$ $\mathrm{cm}^{-1}, r^{2}=0.28, p=0.009$ ), the opposite was found for roach $\left(n=79\right.$, slope $-1.2 \mu \mathrm{g} \mathrm{kg}^{-1} \mathrm{~cm}^{-1}, r^{2}=0.04$, not significant) and perch $\left(n=67\right.$, slope $-4.0 \mu \mathrm{g} \mathrm{kg}^{-1} \mathrm{~cm}^{-1}$, $r^{2}=0.14, p=0.002$ ).

Peterson et al. [29] reported that mercury concentrations of fish with $>12 \mathrm{~cm}$ total length sampled in US rivers were strongly related to both fish length and trophic guild (piscivorous vs. non-piscivorous). Mercury concentration in that study generally increased with fish size, although the (slightly non-linear) relationship showed much scatter [29]. The authors reported that, on average, mercury concentrations only increased with fish length up to a total length of $40-50 \mathrm{~cm}$. The fish investigated in the current study had maximum fish length of $43 \mathrm{~cm}$ (all,

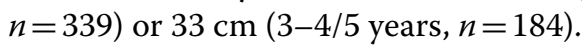

\section{Concentrations of priority substances in fish composite samples and comparison with other studies}

Although the samples from the six investigated sites cannot be regarded as spatially or temporally representative and not all fish composite samples meet the requirements of the RAKON Working Paper [7], the results, together with other available data, may nevertheless indicate which substances are likely or not likely to exceed the EQS in German water bodies. For plausibility checks, fish monitoring data from the German federal states

Table 2 Comparison of mercury concentrations of fish: all fish (aged < 10 years) vs. fish in the age-window recommended for monitoring (3-4 years, for roach 3-5 years; [7])

\begin{tabular}{|c|c|c|c|c|c|}
\hline Age $<10$ years & $\begin{array}{l}\text { Hg fillet } \\
\left(\mu g k^{-1} w w\right)\end{array}$ & $\begin{array}{l}\text { Hg whole fish } \\
\left(\mu g k^{-1} w w\right)\end{array}$ & Age 3-4/5 years ${ }^{a}$ & $\begin{array}{l}\text { Hg fillet } \\
\left(\mu \mathrm{g} \mathrm{kg}{ }^{-1} \mathrm{ww}\right)\end{array}$ & $\begin{array}{l}\text { Hg whole fish } \\
\left(\mu \mathrm{kg}^{-1} \mathrm{ww}\right)\end{array}$ \\
\hline Chub $(n=42)$ & $74 \pm 28$ & $54 \pm 18$ & Chub $(n=23)$ & $62 \pm 21$ & $47 \pm 12$ \\
\hline Roach $(n=123)$ & $49 \pm 40$ & $38 \pm 30$ & Roach $(n=80)$ & $45 \pm 32$ & $36 \pm 26$ \\
\hline Bream $(n=38)$ & $30 \pm 30$ & $24 \pm 24$ & Bream $(n=2)$ & $58 / 5^{b}$ & $50 / 4^{b}$ \\
\hline Whitefish $(n=20)$ & $87 \pm 25$ & $72 \pm 19$ & Whitefish $(n=13)$ & $81 \pm 14$ & $68 \pm 12$ \\
\hline Perch $(n=117)$ & $72 \pm 40$ & $54 \pm 28$ & $\operatorname{Perch}(n=67)$ & $70 \pm 37$ & $53 \pm 26$ \\
\hline All species $(n=340)$ & $60 \pm 40$ & $46 \pm 29$ & All species $(n=185)$ & $58 \pm 34$ & $46 \pm 26$ \\
\hline
\end{tabular}

Data are given as $\mu \mathrm{g} \mathrm{kg}^{-1} \mathrm{ww}$ for fillet and whole fish samples of fish species from all sites (Elbe fish with high mercury concentrations identified as outliers were removed)

a Roach 3-5 years, other fish species 3-4 years

b Bream from Elbe River/Baltic Sea lagoon 

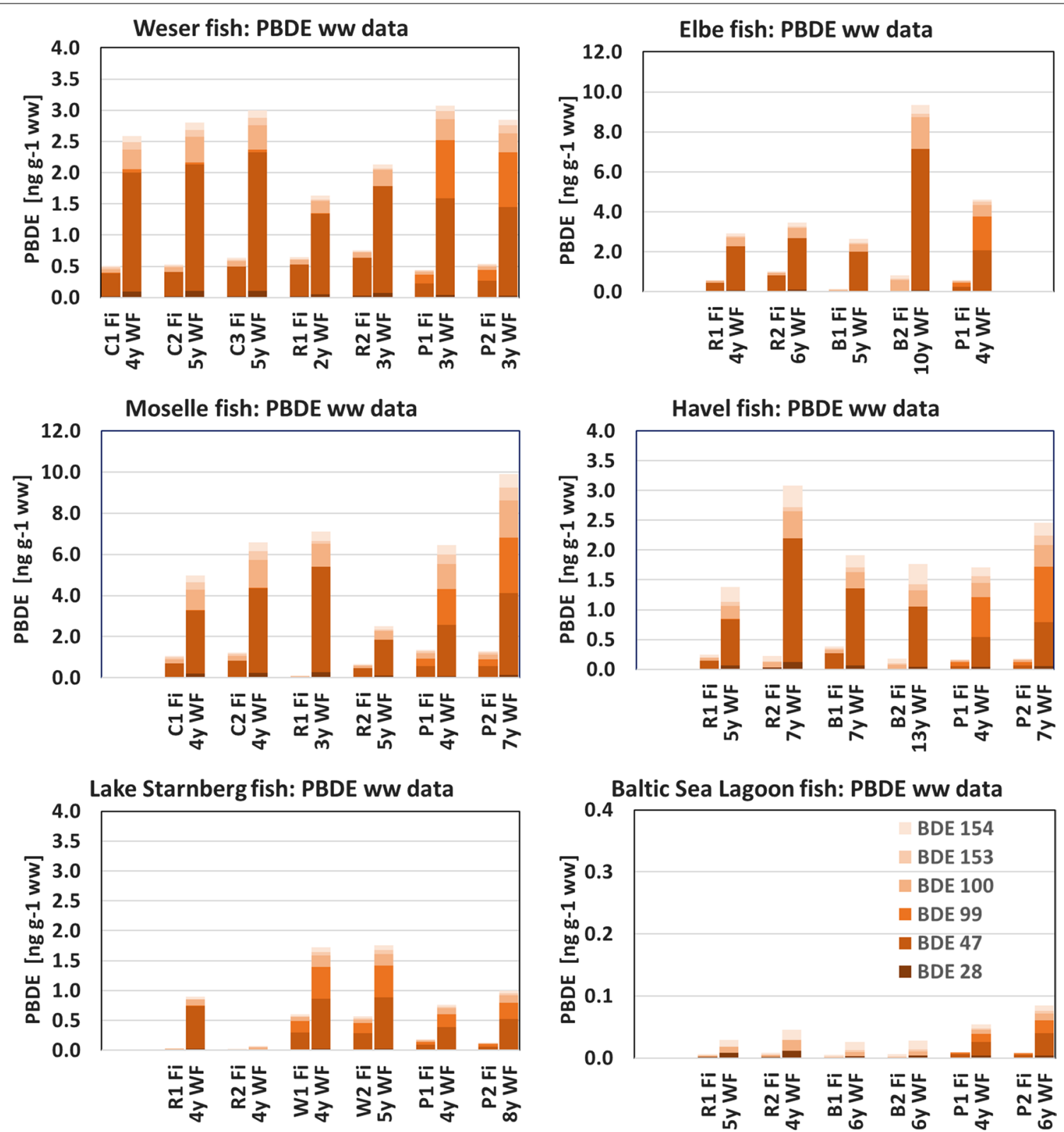

Fig. 1 Concentrations of the sum of six PBDE congeners in fish composite samples from six sites. Data are presented as ng g $\mathrm{g}^{-1}\left(\mu \mathrm{g} \mathrm{kg} \mathrm{g}^{-1}\right)$ on wet weight (ww) basis. C chub, R roach, $B$ bream, $W$ whitefish, $P$ perch, Fi fillet, WF whole fish. Please note the different concentration scales in the diagrams. Concentrations of congeners below the LOQ have been set to $50 \%$ of the respective LOQ

(responsible for the WFD implementation) and other European countries were compared with data from the present study. A direct comparison, however, is only possible for pollution data of fish caught at the same site (or in a certain river section) and in the same year, or in years not too far apart.

In a first step, the concentrations of the priority substances of all examined fillet and whole fish composite samples are compared to the respective EQS. Concentrations of PS grouped per site are illustrated in Figs. 1,
2 and Additional file 1: Figures S5-S8. The figures show the measured fillet concentrations next to the calculated whole fish concentrations (calculated from fillet and carcass data). With the exception of mercury, the concentrations of the investigated substances in the whole fish samples were usually higher than in the corresponding fillet samples. 

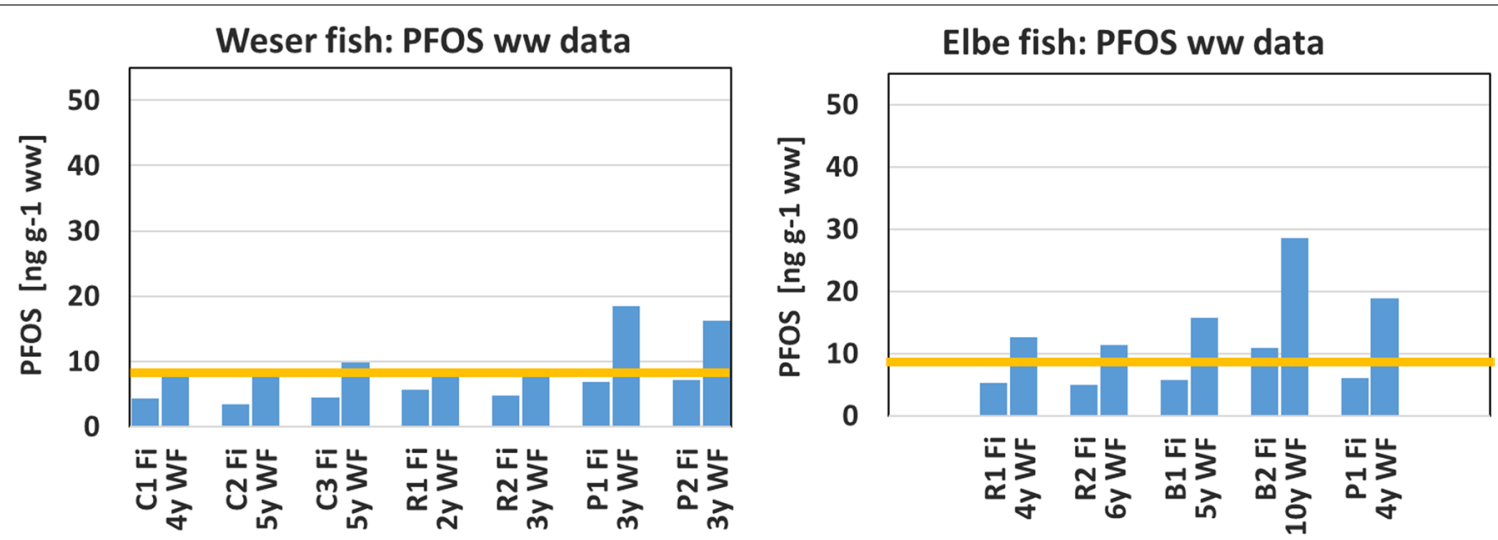

Moselle fish: PFOS ww data

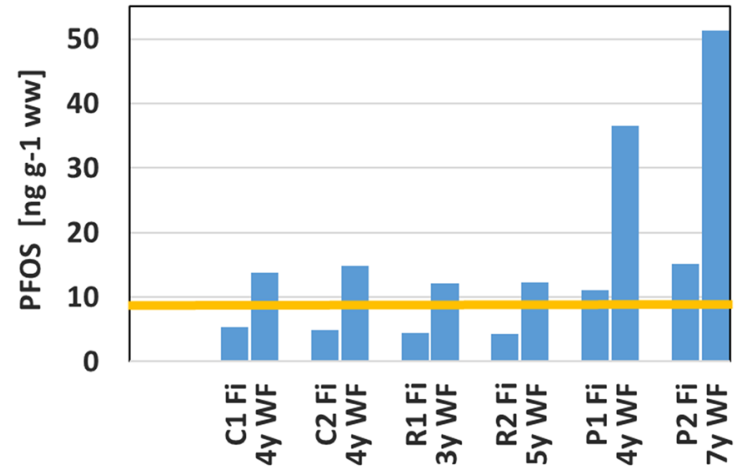

Havel fish: PFOS ww data

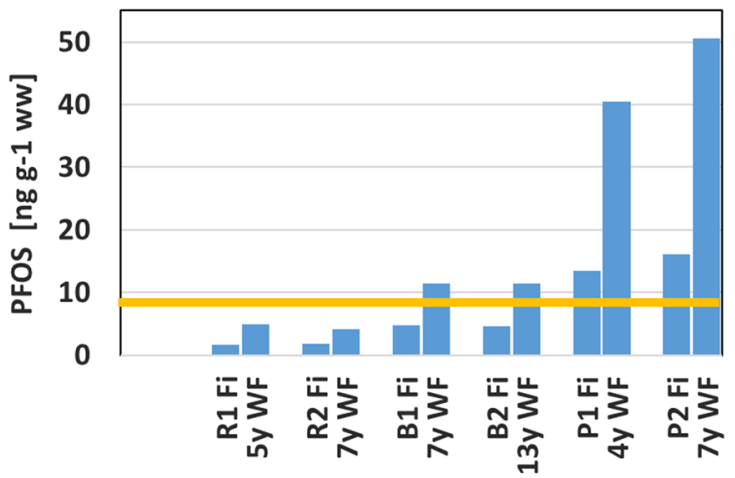

Lake Starnberg fish: PFOS ww data

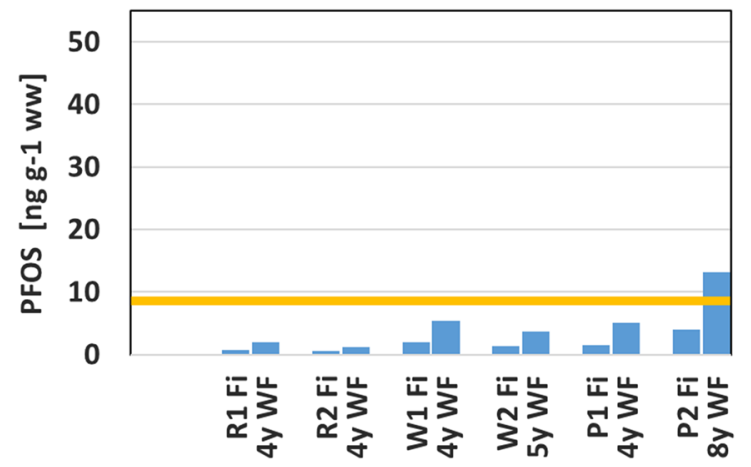

Baltic Sea Lagoon fish: PFOS ww data

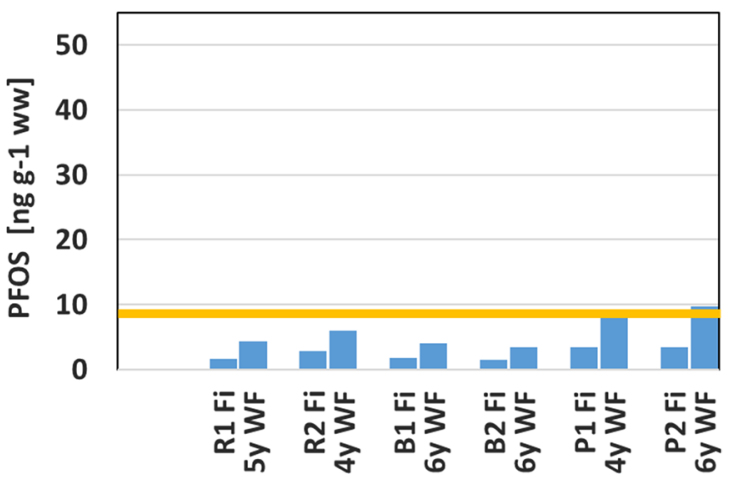

Fig. 2 Concentrations of PFOS in fish composite samples from six sites. Data are presented as $\mathrm{ng} \mathrm{g}^{-1}\left(\mu_{\left.\mathrm{g} \mathrm{kg}^{-1}\right)}\right.$ on wet weight (ww) basis. $C$ chub, $R$ roach, $B$ bream, $W$ whitefish, $P$ perch, Fi fillet, WF whole fish. Horizontal lines mark the EQS for PFOS $\left(9.1 \mathrm{mg} \mathrm{kg}^{-1} \mathrm{ww}\right)$

\section{PBDE}

In Fig. 1 the concentrations for PBDE (sum of six congeners as required for WFD compliance testing) are shown. All but one fillet and all whole fish samples exceed the EQS $\left(0.0085 \mu \mathrm{g} \mathrm{kg}^{-1}\right.$ wet weight; human-health-based with fillet as the EQS-relevant tissue). Highest PBDE burden were found for fish from Moselle and Elbe Rivers, and lowest for fish from the Baltic Sea lagoon. Generally, whole fish PBDE concentrations are significantly higher than the concentrations in fillet (by an average factor of about 5). On average, fat contents of whole fish are about 3.5 times higher than those in fillet (Additional file 1: Table S2; whole fish mean fat content $5.2 \%$, range $1.6-8.4 \%$, vs. fillets mean fat $1.5 \%$, range $0.6-2.6 \%$; both $n=36)$.

A comparison with data for fish fillet from other German water bodies reveals that PBDE concentrations found here (i.e., from $0.0082 \mu \mathrm{g} \mathrm{kg}{ }^{-1} \mathrm{ww}$ for fish from the Baltic Sea lagoon up to $3.35 \mu \mathrm{g} \mathrm{kg}{ }^{-1}$ ww for fish from Elbe River) were in a similar range. In the 
different studies from the period 2013-2018 summarized in Additional file 1: Table S8 mostly PBDE levels of $<\mathrm{LOQ}-16.7 \mu \mathrm{g} \mathrm{kg}-1 \mathrm{ww}$ were found. Only very few samples were compliant with the EQS of $0.0085 \mu \mathrm{g} \mathrm{kg}^{-1} \mathrm{ww}$. However, higher concentrations with up to $371 \mu \mathrm{g} \mathrm{kg}^{-1} \mathrm{ww}$ were found in a set of about 10 -year-old bream samples from larger German rivers [8]. With respect to whole fish samples, Jürgens et al. [30] reported exceedances of the EQS in all analyzed samples (mainly roach) from English rivers in the period 2007-2011. Highest concentrations were measured in fish from the Nene River $\left(5.3-44 \mu \mathrm{g} \mathrm{kg}^{-1}\right)$ and lowest in fish from the Glen River $\left(2.0-4.6 \mu \mathrm{g} \mathrm{kg}^{-1}\right)$. Nation-wide exceedances of the EQS of PBDE in biota were also reported for fish from Sweden [31]. A literature evaluation of PBDE monitoring data from several European countries and other regions came to a similar result: for $25 \%$ of fish samples the sum PBDE concentrations exceeded the EQS, in some samples up to ten thousand times [32].

In this study, the patterns of PBDE in the fillet and whole fish composite samples from the same fish were similar (congener-specific concentration data are shown in Additional file 1: Table S4 and congener fractions in $\%$ in Additional file 1: Table S5). Only for fish from the Baltic Sea lagoon, differences were observed which seemed to be partly caused by low concentration levels (mostly<LOQ) especially in fillet samples where BDE 47 was the only congener above the LOQ. When comparing the PBDE congener patterns of the different fish species, it is apparent that the highest fractions of BDE 99 were found in perch and whitefish (fraction of about $25-35 \%$ of total PBDE), while chub, roach and bream showed only low levels of this congener (range about $0-2 \%$ ). BDE 47, on the other hand, had lower fractions in perch and whitefish (about 30-55\%) than in the other three species (about 50-80\%). Apparently, perch and whitefish did not metabolize the penta-brominated BDE 99, while chub, roach and bream degraded BDE 99 resulting in higher fractions of the tetra-brominated BDE 47. A similar discrepancy was found for BDE 28, which was detected in chub, roach and bream with fractions of about 3-6\% (exception: Elbe River bream with 1-2\%; Baltic Sea lagoon fish not considered because BDE 28 levels were $<$ LOQ in most composite samples), but was comparatively low in perch and whitefish (fractions about 1-3\%). Differences in PBDE metabolization between fish species were already reported, e.g., by Roberts et al. [33] who found that in laboratory investigations with fish liver cells PBDE in carp (cyprinid species related to bream and chub) were metabolized 10-100 times faster than in salmonids. In carp, BDE 47 was the major metabolite of BDE 99 [33]. BDE 28, on the other hand, was observed as metabolite of BDE 47 in fish belonging to the carp family [34]. Fliedner et al. [16] reported that in wild perch sampled in the German part of Danube River BDE 99 was the second most frequent congener (fraction of about 22\%), while in chub and bream from the same site BDE 99 fractions were low. It seems that metabolization in perch was slower as compared to the other species leading to the observed high fractions of BDE 99 [16].

\section{Dioxins and dl-like compounds}

Concentration data for PCDD/F and dl-PCB in fillet and whole fish composite samples are shown in Additional file 1: Figure S5. Whole fish concentrations were always higher than the respective fillet levels. For fillets (relevant matrix for EQS compliance testing) no exceedance of the EQS of $0.0065 \mu \mathrm{g} \mathrm{kg}{ }^{-1} \mathrm{ww}$ as $\mathrm{WHO}_{2005}$-TEQ was observed. Highest levels were found in Elbe and Havel fish with whole fish concentrations partly above the EQS. In all samples, the combined parameter of $\mathrm{PCDD} / \mathrm{F}$ plus dl-PCB was clearly dominated by dl-PCB.

The fish concentrations of PCDD/F and dl-PCB reported in other studies from Germany were also in the range of $0.00006-0.0181 \mu \mathrm{g} \mathrm{kg}^{-1} \mathrm{ww}$ (Additional file 1: Table S8). Concentrations above the EQS were mainly found in older bream from major German rivers [8].

\section{$H C B$}

Additional file 1: Figure S6 presents the data for HCB. The EQS $\left(10 \mu \mathrm{g} \mathrm{kg}^{-1}\right)$ is only exceeded at the Elbe site (for one fillet which is the EQS-relevant matrix, and all whole fish samples). Slightly elevated HCB concentrations were also detected in fish from Weser and Havel Rivers. Generally, HCB concentrations in whole fish were significantly higher than in fillet (by factors of about 3-4).

The data for HCB in fish from other German water bodies are similar (Additional file 1: Table S8; range from $<0.1$ to $44.7 \mu \mathrm{g} \mathrm{kg}^{-1} \mathrm{ww}$ ). However, exceedances of the EQS of $10 \mu \mathrm{g} \mathrm{kg}^{-1}$ were reported only for few samples including eel from the Elbe River [35] which confirm the finding of high levels for Elbe fish in the present study. In whole fish from English rivers, $\mathrm{HCB}$ concentrations were below the EQS with a maximum level of $6 \mu \mathrm{g} \mathrm{kg}^{-1}$ in some eels [30].

\section{PFOS}

The PFOS burden of fish are shown in Fig. 2. For PFOS, the differences between wet weight-based concentrations in fillet and whole fish were smaller compared to the other organic PS (average factor 2.7). At the sampling sites in the Moselle and Havel Rivers, not only whole fish, but also some fillet samples (EQS-relevant matrix) exceeded the EQS of $9.1 \mu \mathrm{g} \mathrm{kg}-1$. At all sites, the EQS is exceeded in at least one of the whole fish samples. It 
is noticeable that at all but one sites highest whole fish concentrations for PFOS are detected in perch (most significantly in Havel and Moselle fish; an exception was the Elbe, where highest PFOS levels were found in 10-yearold bream). At the Havel site, an increase of PFOS concentrations is obvious from roach to bream to perch (Fig. 2). Fish from Lake Starnberg and the Baltic Sea lagoon showed lowest PFOS burden.

PFOS burden of fish from other water bodies in Germany were in the range $<0.2-83.9 \mu \mathrm{g} \mathrm{kg}^{-1}$ (Additional file 1: Table S8). In about half of the fish, the EQS for PFOS $\left(9.1 \mu \mathrm{g} \mathrm{kg}^{-1}\right)$ was exceeded.

\section{Mercury}

Highest mercury concentrations were found in fish from the Elbe River, while lowest levels were measured for fish from Lake Starnberg (for the inland waters investigated) and from the coastal waters of the Baltic Sea lagoon (Additional file 1: Figure S7). Mercury concentrations in most composite samples exceeded the EQS of $20 \mu \mathrm{g} \mathrm{kg}^{-1} \mathrm{ww}$. The only exceptions were roach (all fillet and whole fish samples) from the Moselle, one bream whole fish sample from the Havel and all whole fish and four fillet samples from the Baltic Sea lagoon. The enrichment pattern of mercury differed from that of the organic PS insofar as fillet concentrations were generally higher than whole fish burden (with the exception of a few lowcontaminated fish). This has already been described in other studies (e.g., $[26,29,36])$. Since the EQS for mercury is justified by the risk of secondary poisoning, whole fish is the relevant tissue [5]. If only fillet data are available, these could be used for a worst-case assessment of EQS compliance (the conversion of fillet-to-whole fish concentration data will be discussed below).

A tendency of increasing mercury concentrations with higher trophic levels-as reported by Peterson et al. [29] - was not always recognizable in the present study (however, sometimes the trophic positions of chub and roach or bream and roach at one location were relatively close together, Table 1). At the Moselle site, where the trophic positions of chub and roach were clearly distinguishable from perch, mercury levels differed significantly between trophic levels. In contrast, only small differences in mercury contamination were noticeable between different fish species in Havel River, even though the trophic positions of roach and bream at this site were clearly different from that of perch.

No correlation between the variability of mercury concentrations of the composite samples and parameters such as fish age, number of fish per composite sample or height of mercury levels could be detected (see Additional file 1: "Variability of the mercury burden of the individual fish used for preparing the composite samples" section).

The fact that most European fish exceed the EQS of $20 \mu \mathrm{g} \mathrm{kg}^{-1}$ for mercury is well known (e.g., [22, 30, 3638]). Fish fillet from other German sampling sites (Additional file 1: Table S8) had mercury burden in the range 6-1915 $\mu \mathrm{g} \mathrm{kg}^{-1}$.

\section{$H B C D D$}

The second investigated compound with an EQS referring to secondary poisoning is HBCDD (Additional file 1: Figure S8). For this compound, whole fish concentrations were not always higher than the respective fillet levels and data were generally less consistent. In some cases, even higher concentrations were detected in fillet despite higher fat contents in whole fish (e.g., sample chub 2 from the Weser, or sample perch 1 from the Baltic Sea lagoon). Patterns of HBCDD diastereomers were also not uniform. In some samples, $\gamma$-HBCDD dominated, while mostly $\alpha$ - and $\gamma$-HBCDD were in the same range. $\beta$-HBCDD concentrations in both fillet and whole fish were mostly low compared to the other diastereomers. All samples complied with the EQS for HBCDD of $167 \mu \mathrm{g} \mathrm{kg}^{-1}$ ww. Highest HBCDD levels were found in fish from Elbe and Weser, while fish from Lake Starnberg and the Baltic Sea lagoon had comparatively low HBCDD burden (except for outliers). The highest sum HBCDD concentration detected was about $20 \%$ of the EQS (perch whole fish sample from the Elbe).

In Additional file 1: Table S8 HBCDD concentrations in fish from other German rivers are compiled. Sum concentrations of the three HBCDD diastereomers were in the range $<0.003-45.6 \mu \mathrm{g} \mathrm{kg}-1 \mathrm{ww}$ and thus, as in the present study, well below the respective EQS. HBCDD levels in bream sampled in 2013 from five rivers in the UK, Sweden, France, and The Netherlands and one lake in Germany were also below the EQS [39]. Likewise, no exceedance of the EQS was detected in fish of different species sampled at freshwater and coastal sites in Denmark in 2012 [40]. A literature review on HBCDD concentrations in fish of different countries around the world assessed the EQS compliance situation for HBCDD as not critical with only some values exceeding the EQS about five times [32].

\section{Heptachlor/heptachlor epoxide}

The contamination of the fish samples with heptachlor and heptachlor epoxide was always below the LOQs (sum values $<0.2-0.3 \mu \mathrm{g} \mathrm{kg}^{-1} \mathrm{ww}$; Additional file 1: Table S3). EQS compliance, however, could not be assessed because the EQS for this parameter is $0.0067 \mu \mathrm{g} \mathrm{kg}^{-1} \mathrm{ww}$ and thus significantly lower than the LOQ. 
Only in some studies with fish from German water bodies was the LOQ for heptachlor/heptachlor epoxide sufficiently low to allow a compliance check of the EQS of $0.0067 \mu \mathrm{g} \mathrm{kg}^{-1}$ ww (Additional file 1: Table S8). Fish concentrations were in a range of $<0.002-0.514 \mu \mathrm{g} \mathrm{kg}^{-1} \mathrm{ww}$. For freshwater fish from Danish water bodies, Vorkamp et al. [40] reported heptachlor epoxide concentrations ranging from $<0.0016$ to $23 \mu \mathrm{g} \mathrm{kg}{ }^{-1} \mathrm{ww}$ (heptachlor concentrations were below the detection limit).

Figure 3 visualizes the PS concentration range detected in our study in the EQS-relevant tissues for the composite samples of chub, roach and perch in the age range recommended in the RAKON Working Paper [7] in relation to the relevant EQS. The results from this study as well as the retrieved monitoring data from other studies in Germany (Additional file 1: Table S8) show that the EQSs for mercury and PBDE are exceeded almost nation-wide. In contrast, the EQSs for HBCDD, HCBD and dicofol are consistently met (the latter PS were not considered in the present study due to expected low concentrations). $\mathrm{PCDD} / \mathrm{F}+\mathrm{dl}-\mathrm{PCB}$ and $\mathrm{HCB}$ are also below the respective EQS at most sites. The picture for PFOS is much more heterogeneous: here EQS exceedances indicate that some sites are significantly higher contaminated than others. EQS compliance of heptachlor and heptachlor epoxide could not be checked in most cases because the analytical methods used were not sensitive enough (LOQ $>E Q S$ ). Monitoring data from other European countries show a similar picture (see discussion of PS data above). Sweden, for which most data are available, reports that the EQS for mercury and PBDE are exceeded nation-wide, and also the EQS for PFOS is frequently exceeded by freshwater fish [31, 36, 41, 42]. In fish from Swedish inland waters, high concentrations of $\mathrm{PCDD} / \mathrm{F}+\mathrm{dl}-\mathrm{PCB}$ are found. In contrast, HBCDD burden of fish are always and HCB burden mostly below the respective EQS [31].

\section{Comparison of PS burden between species}

Since roach and perch were available at all six sampling sites, data were aggregated and compared (Additional file 1: Table S3, bottom). Interestingly, no large differences were apparent when comparing mean values of the concentrations for most of the investigated PS. However, for PFOS, mercury and HCB (and to a limited extent also for $\mathrm{PCDD} / \mathrm{F}+\mathrm{dl}-\mathrm{PCB})$ mean concentrations in perch were higher than in roach (up to a ratio of 3 for PFOS and HBCDD). Differences were observed for the ratios of PS concentrations in whole fish and fillet. For all substances except mercury, whole fish/fillet ratios were higher in perch than in roach. For the organic PS except HBCDD

\section{EQS and concentration range $\left[\mu \mathbf{~ k g}^{-1} \mathbf{w w}\right]$ on a logarithmic scale}

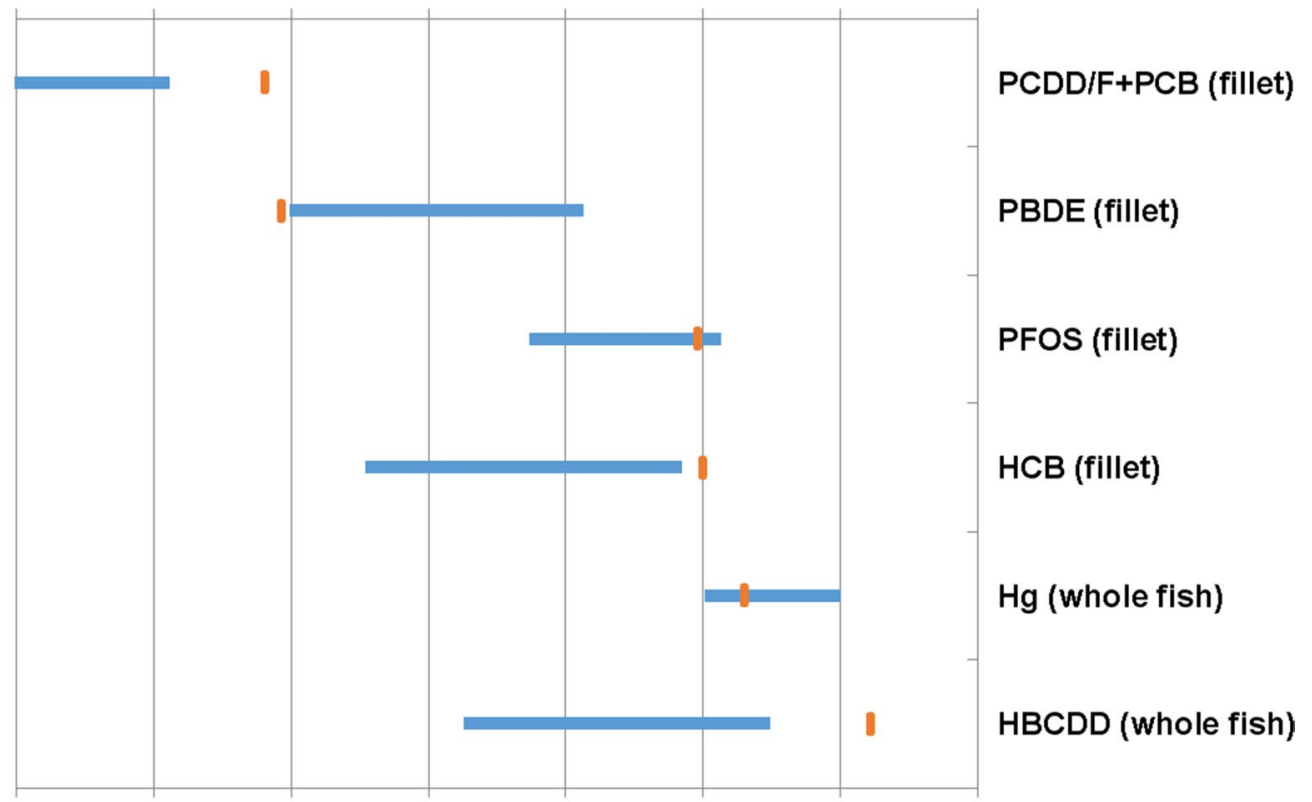

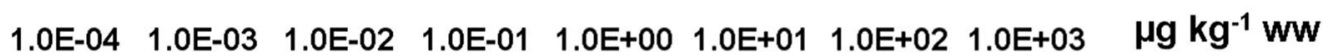

Fig. 3 Concentration range of priority substances ( $\mu \mathrm{g} \mathrm{kg}^{-1}$ wet weight) in composite samples of chub and perch aged 3-4 years and roach aged 3-5 years in relation to the respective EQS (orange bar). For mercury and HBCDD whole fish data are given and for the other compounds fillet data (relevant tissues for EQS compliance testing for the respective PS) 
and PFOS, whole fish/fillet ratios were about 3-5 for roach as compared to about $5-8$ for perch. The respective values for HBCDD were about 1.3 for roach and about 4 for perch, and for PFOS about 2 for roach and about 3 for perch. The observed differences between both species are probably related to different fat contents in whole fish and fillet (Additional file 1: Table S2). Perch had relatively low fillet fat contents with a whole fish/fillet ratio for fat of 4.4 (compared to an average of 3.6 for all fish species). For mercury, no differences in whole fish/fillet ratios were detected between perch and roach (ratio for both about 0.8).

Comparisons of PS concentrations in fish of different sex are presented in Additional file 1: "Priority substances burden of fish of different sex" section. At the two sites, where comparable male/female composite samples of roach could be prepared, the concentrations of some organic PS were higher in male than in female fish (at Lake Starnberg this was the case for PBDE, PCDD/F + dl$\mathrm{PCB}$, and partly $\mathrm{HBCDD}$, and at the Baltic Sea lagoon for whole fish samples of HBCDD, HCB, PBDE, PFOS). These findings can be explained by the higher fat content of male roach at both sites. For mercury, the results were ambiguous for both investigated pairs of male/female fish composite samples.

\section{Derivation of fillet-to-whole fish conversion factors}

The evaluation of the data set with all 36 fillet/whole fish composite sample pairs (data taken from Additional file 1: Table S3) according to Bevelhimer et al. [26] revealed that for $\mathrm{HCB}, \mathrm{PBDE}, \mathrm{HBCDD}$ and PFOS conversion factors can be derived, whereas for PCDD/F + dl-PCB and mercury conversion equations should be used (Table 3 and Additional file 1: Table S6). If only the 20 composite samples with RAKON-compliant fish age [7] are considered, conversion factors could be derived for all substances including mercury (Table 3 and Additional file 1: Table S7). The conversion factors derived from the whole data set $(n=36)$ were similar to those calculated with the composite sample data set with RAKON-compliant fish ages $(n=20)$. For HCB, the high concentrations in Elbe fish apparently did not influence the evaluation since the conversion factors for HCB with and without considering the Elbe fish were almost the same (3.57 and 3.52, respectively). In contrast, the factor for HBCDD changed clearly when outliers were excluded.

\section{Conclusions}

Based on the data generated in this project and from other reports, further recommendations on important aspects regarding the biota monitoring in the context of the European WFD can be made.

\section{Are the recommendations regarding the fish species applicable?}

The fish species chub, roach, bream and perch (representatives of trophic levels 3-4), which were examined here in several German water bodies, fulfill the requirements for biota monitoring of priority substances for the WFD and proved to be suitable in practical implementation. At least two fish species per site were present in sufficient abundance. With the exception of bream, fish of the intended age [7] could be sampled at almost all sites (fish aged 3-4 years, respectively, 3-5 years for roach).

\section{How much fish tissue is required for the analysis?}

In view of the lower costs for chemical analysis and the possibility to determine all pollutants in one sample (which in turn offers the possibility of a plausibility check), the analysis of suitable composite samples is recommended. However, thorough homogenization is a prerequisite for the quality of the analytical results. The individual fish should be included in the composite sample proportionally to their total mass (e.g., whole fish or whole fillet mass), as this best reflects natural conditions: small and large fish also contribute proportionally

Table 3 Fillet-to-whole fish conversion factors and equations for priority substances (for all fish, $n=36$, and for 3-4 years/3-5 years fish, $n=20$ )

\begin{tabular}{|c|c|c|}
\hline Priority substance & $\begin{array}{l}\text { Conversion factor (or equation) fillet-to-whole fish (for } \\
\text { all fish, } n=36 \text { ) (significance level, one tailed) }\end{array}$ & $\begin{array}{l}\text { Conversion factor fillet-to-whole fish (for 3-4 years/3-5 years } \\
\text { fish, } n=20 \text { ) (significance level, one tailed) }\end{array}$ \\
\hline$P C D D / F+d l-P C B$ & In (conc. $\left._{\text {whole fish }}\right)=1.56+0.63 *{ }^{*}$ (n conc. $\left._{\text {.fillet }}\right)(p<0.0001)$ & $5.3(p<0.0001)$ \\
\hline HCB & $3.7(p<0.0001)$ & $3.6(p<0.0001)$ \\
\hline PBDE & $5.2(p<0.0001)$ & $5.4(p<0.0001)$ \\
\hline $\mathrm{HBCDD}$ & $1.7(p<0.0001)$ & $1.8(p=0.030)^{\mathrm{a}}$ \\
\hline PFOS & $2.6(p<0.0001)$ & $2.7(p<0.0001)$ \\
\hline Mercury & In (conc.whole fish $)=-0.031+0.949 *\left(\right.$ In conc. $\left._{\text {fillet }}\right)(p<0.0001)$ & $0.81(p<0.0001)$ \\
\hline
\end{tabular}

The conversion method was derived according to the approach described by Bevelhimer et al. [26]

a Outliers removed $(n=15)$ 
to the food intake by humans or top predators. In order to be able to carry out chemical analyses of all PS that have to be monitored in fish with the required sensitivity (i.e., with a LOQ of $30 \%$ of the EQS concentration [12]), about $100-200 \mathrm{~g}$ of sample material is required. Since the amount of fillet of one (small) fish does not yield this amount, it seems more appropriate to prepare composite samples with sufficient amounts of tissue to run all PS analyses (for whole fish 2-3 times more material is available as compared to the fillet). For one complete analysis, fillet of about ten specimens of smaller fish are needed. According to the German Surface Water Ordinance [6], at least ten individuals have to be used per site and year for trend monitoring. Thus, this number of fish also seems suitable for EQS compliance monitoring and has also been incorporated as requirement into the RAKON Working Paper [7]. However, if the fish are very homogeneous in size and age, the RAKON Working Paper also considers a smaller number of fish to be sufficient (assuming that the fish yield sufficient fillet for the analysis).

\section{Do older fish have higher PS burden than younger ones?}

Due to limited fish material and resources this question could only be investigated for mercury on an individual fish basis. However, the relationships between age (operationalized as fish length) and mercury burden at the different sites were ambiguous (refer to "Mercury concentrations in individual fish samples" section). For the organic PS only fish composite samples could be investigated which allow merely a comparison of younger fish (3-4 years, or 3-5 years for roach; $n=20$ ) and older fish $(>4 / 5$ years; $n=15)$. For these, a tendency of higher PS levels in older fish was apparent (Additional file 1: Table S9). For $\mathrm{PCDD} / \mathrm{F}+\mathrm{dl}-\mathrm{PCB}$, the concentrations in the $\mathrm{EQS}$ relevant fillet composite samples were on average 104\% higher in fish aged $>4-5$ years than in those in the recommended age groups of 3-4 years/3-5 years according to the RAKON Working Paper [7]. Similar results were found for PBDE (+37\%), PFOS (+22\%), and HCB (+157\%). The mercury whole fish samples (EQS-relevant) were also $28 \%$ higher in the older fish. For HBCDD, on the contrary, the concentrations in the whole fish samples of the older fish were $46 \%$ lower compared to the 3-4/3-5-year-aged fish. Thus, it seems advantageous to stratify fish catches by age to get more homogenous results.

\section{Which trophic level should the fish represent?}

Although, all fish species had a trophic level of about 3-4 as recommended, at least for some compounds (especially PFOS) and some locations, higher concentrations in fish of higher trophic level were observed. To assure that the determined fish concentrations used for the EQS compliance check are protective, predatory fish ( $\mathrm{TL} \geq 4)$ such as perch seem to be more appropriate for the EQS compliance testing.

\section{Should fillet or whole fish be analyzed?}

For HCBD, dicofol, HBCDD, and mercury, the EQS is based on the protection goal "prevention of secondary poisoning of wildlife". In order to estimate the respective risk, the analysis of whole fish seems to be the most meaningful method. In contrast, the EQSs for PBDE, $\mathrm{HCB}, \mathrm{PFOS}, \mathrm{PCDD} / \mathrm{F}+\mathrm{dl}-\mathrm{PCB}$ and heptachlor/heptachlor epoxide are based on the protection of "human health". For this purpose, fillet seems to be the suitable matrix for analysis. According to the RAKON Working Paper [7], the German monitoring strategy is primarily oriented towards the "human health" protection goal. Accordingly, the substance contents in the edible part of the fish (fillet) should be determined.

\section{Can factors be derived to convert fillet concentrations of contaminants into whole fish concentrations (or vice versa)?}

For this project, pollutant concentrations were determined in composite samples of both, fillet and whole fish (calculated from fillet and carcass samples) so that conversion-factors or -equations could be derived according to the concept of Bevelhimer et al. [26]. This approach allows converting the substance concentrations to the tissue relevant for the respective protection goal if only one matrix (fillet or whole fish) is examined. However, the extent to which the conversions can be transferred also to other waters and other fish species needs further examination. Fliedner et al. [16] yielded different results for PFOS and mercury for fish from one German Danube River site. In that study, however, mostly older fish were covered. For fish of the recommended age class of 3-4 years (3-5 for roach) [7] fillet-to-whole fish conversion factors could be derived for all investigated PS in this study. Thus, it is feasible to determine the PS concentrations only in one tissue (e.g., fillet as considered in Germany [7]); check the compliance directly in fillet for the human health-based EQSs and convert the concentrations to whole tissue concentrations for those PS where the EQS is based on wild life protection.

\section{Considerations on selection of fish for EQS compliance testing}

In principle, it would be more appropriate to adapt the fish length recommended for biota monitoring to the food spectrum of the protected species under consideration. For the protection goal "human health" (consumption of fish), which is the justification for the EQSs of $\mathrm{PCDD} / \mathrm{F}+\mathrm{dl}-\mathrm{PCB}, \mathrm{PBDE}, \mathrm{HCB}$, heptachlor/heptachlor 
epoxide and PFOS, the fillets of larger fish $(>30 \mathrm{~cm})$ are more likely to be relevant. For dicofol, HBCDD, HCBD and mercury, the EQSs are based on the "prevention of secondary poisoning of wild animals" and smaller fish seem more relevant since only very large top predators feed on larger specimens. However, for the fish in the age class 3-4 years (3-5 for roach) investigated in this study, a broad range of fish lengths was found. Thus, it has to be emphasized that in an age-based selection, fish from different locations can vary greatly in size depending on biotic and abiotic environmental factors (e.g., food conditions in the water). Accordingly, a fairly simple lengthbased selection of fish used for monitoring would allow a better alignment of the fish catch to the relevant protection goal than the age class.

\section{Supplementary information}

Supplementary information accompanies this paper at https://doi. org/10.1186/s12302-020-0295-9.

Additional file 1. Detailed data tables, additional figures and supporting information on evaluations. Table S1. Characterization of the investigated fish by length, weight, sex, age and condition factor. Table S2. Results of the fat determinations (Smedes method) and dry mass measurements. Table S3. Concentrations of priority substances in fish composite samples. Table S4. Concentrations of six PBDE congeners in fish composite samples. Table S5. Fractions of PBDE congeners in fish composite samples. Table S6. Testing of the correlation between the logarithmized priority substance concentrations in fillet and whole fish samples ( $n=36$; composite samples) and derivation of fillet-to-whole fish conversion factors or -equations. Table S7. Testing of the correlation between the logarithmized priority substance concentrations in fillet and whole fish composite samples ( $n=20 ; 3-4$ y old fish/3-5 y for roach) and derivation of fillet-towhole fish conversion factors or -equations. Table S8. Overview over the German monitoring data of relevant WFD priority substances in fish fillet compiled from the literature (period: 2013-2018). Table S9. Comparison of average concentrations of priority substances in composite samples of fish of different age classes. Figure S1. Correlation of age vs. length for roach and perch from all sampling sites. Figure S2. Correlation of age vs. length for 3-5 year-aged roach and 3-4 year-aged perch from all sampling sites. Figure S3. Plot and linear regression of mercury concentrations in whole fish from all sampling sites vs. length for 3-4 y-aged fish (3-5 y for roach). Figure S4. Plot and linear regression of mercury concentrations in whole fish vs. length for 3-4 y-aged fish (3-5 y for roach); separate evaluation for each water body investigated. Figure S5. Sum of concentrations of PCDD/F and dl-PCB in fish composite samples from six water bodies. Figure S6. Concentrations of HCB in fish composite samples from six sites. Figure S7. Concentrations of mercury $(\mathrm{Hg})$ in fish composite samples from six water bodies. Figure S8. Concentrations of HBCDD (sum of three diastereomers) in fish composite samples from six water bodies. Figure S9. Correlation between logarithmized PFOS concentrations in paired fillet and whole fish composite samples. Figure S10. Correlation between logarithmized HBCDD concentrations in paired fillet and whole fish composite samples. Figure $\mathbf{S 1 1}$. Correlation between logarithmized mercury concentrations in paired fillet and whole fish composite samples. Section "Exemplary calculation showing the possible influence of removing livers and brains from some carcass samples on the PS concentrations in the carcass samples". Section "Variability of the mercury burdens of the individual fish used for preparing the composite samples". Table A1. Calculated mercury concentration mean values and standard deviations of individual fish used for the preparation of the composite samples. Section "Priority substances burdens of fish of different sex". References cited in the Additional file.

\section{Abbreviations}

B: Bream; C: Chub; CF: Condition factor; CRM: Certified reference material; dl-PCB Dioxin-like polychlorinated biphenyls; ESB: Environmental Specimen Bank; EQS: Environmental quality standard; Fi: Fillet; GC-MS/MS: Gas chromatography coupled to tandem mass spectrometry; GC-MS: Gas chromatography coupled to mass spectrometry; HBCDD: Hexabromocyclododecanes; HCB: Hexachlorobenzene; HCBD: Hexachlorobutadiene; Hg: Mercury; HPLC-MS/MS: High performance liquid chromatography coupled to mass spectrometry; HRMS: High-resolution gas chromatography; LOD: Limit of detection; LOQ: Limit of quantification; P: Perch; PBDE: Polybrominated diphenyl ethers; PCDD/F: Polychlorinated dibenzo-p-dioxins and -furans (short: dioxins); PFOS: Perfluorooctane sulfonic acid and its derivatives; PS: Priority substances; R: Roach; RAKON: Framework Concept Monitoring (German abbreviation); SD: Standard deviation; TEQ: Toxic equivalency factor; W: Whitefish; WF: Whole fish; WFD: Water Framework Directive; WHO: World Health Organization; ww: Wet weight; $y$ : Years.

\section{Acknowledgements}

The authors thank the teams of agroisolab $\mathrm{GmbH}$, Jülich (stable isotope analysis), Büro für Fisch- und Gewässerökologie, Hamburg, S. Oesmann (sampling at Elbe River), Institut für Angewandte Ökologie Dr. Schwevers, Kirtorf-Wahlen, B. Adam and T. Kirchner (fish age determination). NLWKN Niedersächsische Landesbetrieb für Wasserwirtschaft, Küsten- und Naturschutz, Hildesheim (D. Steffen), LAVES Niedersächsische Landesamt für Verbraucherschutz und Lebensmittelsicherheit (L. Meyer), Fischereiamt Berlin (J. Grzegorzewski), Senatsverwaltung für Umwelt, Berlin (D. von Seggern), LfU Landesamt für Umwelt Bayern (G. Buchmeier), LUNG Landesamt für Umwelt, Naturschutz und Geologie (C. Engelke), IfAÖ Institut für Angewandte Ökosystemforschung GmbH Neubroderstorf (J. Gercken), Fischereigenossenschaft Kleines Haff e.V. Ueckermünde, and Landesamt für Umwelt Rheinland-Pfalz (L. Kroll) are thanked for the support of the sampling campaigns. P. Lepom (formerly German Environment Agency) is gratefully thanked for the initiation of this study. The authors acknowledge the dedicated work of the whole ESB team of Fraunhofer IME and the laboratory team of Eurofins GfA Lab Service in support of this investigation.

\section{Authors' contributions}

$H R, G R$ and $A D$ conceived the project; HR and GR managed the sampling campaigns and organized the analyses of the samples; GR conducted the mercury analyses; NL ran the analyses of organic compounds and summarized these data; HR, GR, AF and AD evaluated the data and prepared the submitted manuscript. All authors read and approved the final manuscript.

\section{Funding}

The project "Concept for the implementation of the new environmental quality standards for priority substances in fish (Konzept zur Implementierung der neuen Umweltqualitätsnormen für prioritäre Stoffe in Fischen)" was funded by the German Environment Agency (FKZ 371522200 0).

\section{Availability of data and materials}

All data supporting the conclusions of this article are included within the article and one Additional file.

\section{Ethics approval and consent to participate}

Sampling and killing of wild fish were performed by federal state authorities or authorized fishermen by applying approved methods.

\section{Consent for publication}

Not applicable.

\section{Competing interests}

The authors declare that they have no competing interests.

\section{Author details}

${ }^{1}$ Department Environmental Specimen Bank and Elemental Analysis, Fraunhofer Institute for Molecular Biology and Applied Ecology (Fraunhofer IME), 57392 Schmallenberg, Germany. ${ }^{2}$ Eurofins GfA Lab Service GmbH, Neuländer Kamp 1a, 21079 Hamburg, Germany. ${ }^{3}$ German Environment Agency (Umweltbundesamt), 14193 Berlin, Germany.

Received: 7 November 2019 Accepted: 22 January 2020

Published online: 07 February 2020 


\section{References}

1. EC (2000) Directive 2000/60/EC of the European Parliament and of the Council of 23 October 2000 establishing a framework for community action in the field of water policy. Official Journal of the European Communities, pp L327/1-72. https://eur-lex.europa.eu/legal-content/EN/ TXT/?uri=celex\%3A32000L0060

2. EU (2013) Directive 2013/39/EU of the European Parliament and of the Council of 12 August 2013 amending Directives 2000/60/EC and $2008 / 105 / E C$ as regards priority substances in the field of water policy. Official Journal of the European Communities, pp L226/1-17. https ://publications.europa.eu/en/publication-detail/-/publication/296e9 1b8-4610-11e3-ae03-01aa75ed71a1/language-en

3. EC (2008) Directive 2008/105/EC of the European Parliament and of the Council on environmental quality standards in the field of water policy and amending Directive 2000/60/EC. Official Journal of the European Communities, pp L 348/84-97

4. EC (2011) Guidance document no. 27: technical guidance for deriving environmental quality standards. Common implementation strategy for the Water Framework Directive (2000/60/EC). Technical report-2011-055. ISBN 978-92-79-16228-2, Office for Official Publications of the European Communities, Luxembourg. https://circabc.europ a.eu/sd/a/0cc3581b-5f65-4b6f-91c6-433a1e947838/TGD-EQS\%20CIS -WFD\%2027\%20EC\%202011.pdf

5. EC (2014) Guidance Document No. 32 on biota monitoring: (the implementation of EQSbiota) under the Water Framework Directive. Common implementation strategy for the Water Framework Directive (2000/60/ EC). Technical report-2014-083. ISBN 978-92-79-44634-4, Office for Official Publications of the European Communities, Luxembourg. https:// circabc.europa.eu/sd/a/62343f10-5759-4e7c-ae2b-12677aa57605/Guida nce\%20No\%2032\%20-\%20Biota\%20Monitoring.pdf

6. OGewV (2016) German Surface Water Ordinance. Verordnung zum Schutz der Oberflächengewässer (Oberflächengewässerverordnung OGewV) vom 20. Juni 2016. BGBI. I S. 1373. http://www.gesetze-im-inter net.de/ogewv_2016/OGewV.pdf

7. LAWA-AO (2016) Framework concept monitoring: working paper on biota monitoring. Rahmenkonzeption Monitoring, Teil B: Bewertungsgrundlagen und Methodenbeschreibungen. Arbeitspapier IV.3. Konzeption für Biota-Untersuchungen zur Überwachung von Umweltqualitätsnormen gemäß RL 2013/39/EU. Status: 27.10.2016 (German Language)

8. Fliedner A, Lohmann N, Rüdel H, Teubner D, Wellmitz J, Koschorreck J (2016) Current levels and trends of selected EU Water Framework Directive priority substances in freshwater fish from the German environmental specimen bank. Environ Pollut 216:866-876

9. IKSR (2018) Statistische Auswertung von Messungen zur Kontamination von Biota/Fischen mit Schadstoffen im Einzugsgebiet des Rheins in den Jahren 2014/2015. Internationale Kommission zum Schutz des Rheins (IKSR), Hrsg. Koblenz, 2018 (German language)

10. LUNG (2016) Trendmonitoring von Schadstoffen in Fischen aus Gewässern Mecklenburg-Vorpommerns, Monitoring 2015, Zusammenfassung 2013-2015. Schriftenreihe des Landesamtes für Umwelt, Naturschutz und Geologie Mecklenburg-Vorpommern 2016, Heft 3, p 35. https://www.lung mv-regierung.de/dateien/bzg_wrrl-monitoring_schadstoffe fische_20132017_lung_2018-4.pdf (German language)

11. TLUG (2018) Biota-Monitoring in Thüringen. Bericht. Thüringer Landesanstalt für Umwelt und Geologie (TLUG), Jena. Januar 2018. p 10. https://www. thueringen.de/mam/th8/tlug/content/wasser/fliessgewaesserguete/monit oringbericht/biotabericht_bis_2017_internet.pdf (German language)

12. EC (2009) Comission Directive 2009/90/EC of 31 July 2009 laying down, pursuant to Directive 2000/60/EC of the European Parliament and of the Council, technical specifications for chemical analysis and monitoring of water status (QA/QC-Directive), Official Journal of the European Union L 201/36-38

13. Froese R, Pauly DE (2019) FishBase - a global information system on fishes. World Wide Web electronic publication. Version (02/2019). www.fishbase. org

14. FAO (1974) Chapter 4. Age determinations and age compositions. In: Holden MJ, Raitt DFS (eds) Manual of fisheries science, Part 2-methods of resource investigation and their application. Food and Agriculture Organization of the United Nations (FAO), Rome
15. Rüdel $H$, Weingärtner $M$ (2008) Storage of environmental samples under cryogenic conditions. Guidelines for sampling and sample processing. Version 2.0.0. December 2008, Fraunhofer IME, Schmallenberg, Germany and German Environment Agency, Dessau-Rosslau, Germany. https:// www.umweltprobenbank.de/upb_static/fck/download/IME_SOP_stora ge_Dez2008_V200.pdf

16. Fliedner A, Rüdel H, Lohmann N, Buchmeier G, Koschorreck J (2018) Biota monitoring under the Water Framework Directive: on tissue choice and fish species selection. Environ Pollut 235:129-140

17. Rüdel H, Uhlig S, Weingärtner M (2008) Pulverisation and homogenisation of environmental samples by cryomilling. Guidelines for sampling and sample processing. Version 2.0.0. December 2008, Fraunhofer IME, Schmallenberg, Germany and German Environment Agency, Dessau-Rosslau, Germany. https://www.umweltprobenbank.de/upb_static/fck/download/ IME_SOP_preparation_Dez2008_V200.pdf

18. Post DM (2002) Using stable isotopes to estimate trophic position: models, methods, and assumptions. Ecology 83:703-718

19. Fliedner A, Rüdel H, Knopf B, Weinfurtner K, Paulus M, Ricking M, Koschorreck J (2014) Spatial and temporal trends of metals and arsenic in German freshwater compartments. Environ Sci Pollut Res 21:5521-5536

20. Radermacher G, Fliedner A, Rüdel H (2019) Concept for the implementation of the new environmental quality standards for priority substances in fish (Konzept zur Implementierung der neuen Umweltqualitätsnormen für prioritäre Stoffe in Fischen). German language report on project FKZ 3715 22200 0. UBA-Texte 96/2019 (August 2019). Fraunhofer IME, Schmallenberg, Germany for German Environment Agency, Dessau-Rosslau, Germany. p 180 https://www.umweltbundesamt.de/publikationen/konzept-zur-imple mentierung-der-neuen

21. Rüdel H, Kösters J, Homrighausen D (2011) Determination of mercury in environmental samples by direct solid analysis, guidelines for chemical analysis, German Environmental Specimen Bank. Fraunhofer IME, Schmallenberg, Germany/Umweltbundesamt, Dessau-Rosslau, Germany. https:// www.umweltprobenbank.de/upb_static/fck/download/SOP_DMA_en.pdf

22. Nguetseng R, Fliedner A, Knopf B, Lebreton B, Quack M, Rüdel H (2015) Retrospective monitoring of mercury in fish from selected European freshwater and estuary sites. Chemosphere 134:427-434

23. Van den Berg M, Birnbaum LS, Denison M, De Vito M, Farland W, Feeley M, Fiedler H, Hakansson H, Hanberg A, Haws L, Rose M, Safe S, Schrenk D, Tohyama C, Tritscher A, Tuomisto J, Tysklind M, Walker N, Peterson RE (2006) The 2005 World Health Organization reevaluation of human and Mammalian toxic equivalency factors for dioxins and dioxin-like compounds. Toxicol Sci 93:223-241

24. Smedes F (1999) Determination of total lipid using non-chlorinated solvents. Analyst 124:1711-1718

25. DIN 32645 (2008) Chemische Analytik - Nachweis-, Erfassungs- und Bestimmungsgrenze unter Wiederholbedingungen - Begriffe, Verfahren, Auswertung Beuth Verlag, Berlin

26. Bevelhimer MS, Beauchamp JJ, Sample BE, Southworth GR (1997) Estimation of whole-fish contaminant concentrations from fish fillet data. Technical report ES/ER/TM-202, Oak Ridge National Laboratory, Oak Ridge, USA. https://rais.ornl.gov/documents/tm202.pdf

27. Anderson C, Cabana G (2007) Estimating the trophic position of aquatic consumers in river food webs with nitrogen isotopes. J N Am Benthol Soc 26:273-285

28. Rybczynski SM, Walters DM, Fritz KM, Johnson BR (2008) Comparing trophic position of stream fishes using stable isotope and gut contents analyses. Ecol Freshw Fish 17:199-206

29. Peterson SA, Van Sickle J, Herlihy AT, Hughes RM (2007) Mercury concentration in fish from streams and rivers throughout the western United States. Environ Sci Technol 41:58-65

30. Jürgens MD, Johnson AC, Jones KC, Hughes D, Lawlor AJ (2013) The presence of EU priority substances mercury, hexachlorobenzene, hexachlorobutadiene and PBDEs in wild fish from four English rivers. Sci Total Environ 461-462:441-452

31. Swedish_Environmental_Protection_Agency (2017) National implementation plan for the Stockholm Convention. Report 6794. Swedish Environmental Protection Agency, Stockholm (S). p 122. http://www.swedishepa.se/ Documents/publikationer6400/978-91-620-6794-6.pdf?pid=21458

32. Eljarrat E, Barcelo D (2018) How do measured PBDE and HCBD levels in river fish compare to the European Environmental Quality Standards? Environ Res 160:203-211 
33. Roberts SC, Noyes PD, Gallagher EP, Stapleton HM (2011) Species-specific differences and structure-activity relationships in the debromination of PBDE congeners in three fish species. Environ Sci Technol 45:1999-2005

34. Zhang F, Lu G, Liu J, Yan Z, Zhang Z (2014) Bioaccumulation, distribution and metabolism of BDE-153 in the freshwater fish Carassius auratus after dietary exposure. Ecotoxicol Environ Safety 108:16-22

35. NLWKN (2016) Biota-Schadstoffuntersuchungen in niedersächsischen Gewässern entsprechend der Europäischen Wasserrahmenrichtlinie. Niedersächsischer Landesbetrieb für Wasserwirtschaft, Küsten- und Naturschutz (NLWKN), Hrsg. Bericht. Hildesheim, Januar 2016. p 15. https://www. nlwkn.niedersachsen.de/download/106310/Biota_Schadstoffuntersuchu ngen_in_niedersaechsischen_Gewaessern_entsprechend_der_Europaeisc hen_Wasserrahmenrichtlinie_....._Ausgabe_1_2016.pdf

36. Fauxneld S, Danielsson S, Nyberg E, Bignert A (2015) Conversion factors for metals between liver, muscle and whole body in perch. Report $\mathrm{nr}$. 1/2015. Swedish Museum of Natural History, Department of Environmental Research and Monitoring, Stockholm, Sweden. p 35. https://www.divaportal.org/smash/get/diva2:811293/FULLTEXT01.pdf

37. Lepom P, Irmer U, Wellmitz J (2012) Mercury levels and trends (1993-2009) in bream (Abramis brama L.) and zebra mussels (Dreissena polymorpha) from German surface waters. Chemosphere 86:202-211

38. Foekema EM, Kotterman M, Hoek-van Nieuwenhuizen M (2016) Chemische biotamonitoring conform KRW. Methodeontwikkeling en compliancecheck 2014/2015. IMARES rapport C082/16. 91 S., IMARES Wageningen UR (University \& Research centre), Wageningen, NL
39. Rüdel H, Müller J, Nowak J, Ricking M, Klein R, Kotthoff M (2017) Hexabromocyclododecane diastereomers in fish and suspended particulate matter from selected European waters-trend monitoring and environmental quality standard compliance. Environ Sci Pollut Res 24:18048-18062

40. Vorkamp K, Bossi R, Bester K, Bollmann UE, Boutrup S (2014) New priority substances of the European Water Framework Directive: biocides, pesticides and brominated flame retardants in the aquatic environment of Denmark. Sci Total Environ 470-471:459-468

41. Miller A, Bignert A, Porvari P, Danielsson S, Verta M (2013) Mercury in Perch (Perca fluviatilis) from Sweden and Finland. Water Air Soil Pollut 224:1472

42. Norström K, Viktor T, Palm Cousins A, Rahmberg M (2015) Risks and effects of the dispersion of PFAS on aquatic, terrestrial and human populations in the vicinity of International Airports. Final report of the RE-PATH project 2009-2014. Report B 2232. IVL, Stockholm (S). https://www.ivl.se/ download/18.343dc99d14e8bb0f58b4ffo/1443169730471/B2232_REPATH+FINAL+(3).pdf

\section{Publisher's Note}

Springer Nature remains neutral with regard to jurisdictional claims in published maps and institutional affiliations.

\section{Submit your manuscript to a SpringerOpen ${ }^{\circ}$ journal and benefit from:}

- Convenient online submission

- Rigorous peer review

- Open access: articles freely available online

- High visibility within the field

- Retaining the copyright to your article

Submit your next manuscript at $>$ springeropen.com 